https://doi.org/10.15407/gpimo2020.02.024

\author{
А.Е. Лукин, академик НАН Украины, \\ доктор геол.-мин. наук, профессор \\ Институт геологических наук НАН Украины, Киев \\ 01063, м. Київ, вул. Олеся Гончара, 55-б, \\ E-mail: lukin_alexander@ukr.net \\ ORCID 0000-0003-4844-1617

\section{РАННЕВИЗЕЙСКИЙ ЭВКСИНСКИЙ БАССЕЙН В СИСТЕМЕ ПАЛЕОТЕТИСА (в свете современных данных)}

Среди древних разновозрастных бассейнов эвксинского типа особо выделяется своим удивительным сходством с Черным морем ранневизейский бассейн, фрагменты которого приурочены $\kappa$ Днепровско-Донецкой впадине, а также Придобруджинскому прогибу. Указанное сходство прежде всего относится к сопоставлению голоцена Черного моря и интервала, соответствующего рудовским слоям нижнего визе. Это типичные черносланцевые (гидрокарбопелитовые) формации, которые накапливаются в условиях интенсивной газоотдачи $\left(\mathrm{CH}_{4}-\mathrm{H}_{2} \mathrm{~S}-\mathrm{CO}_{2}\right)$ дна морского бассейна с ограниченной циркуляцией и анаэробными микробиогенными факторами седиментации. $B$ Придобруджинско-Днепровско-Донеиком эвксинском бассейне раннекаменноугольный этап седиментации в условиях эвксинского режима включал в себя также турнейско-ранневизейскую фазу карбонатонакопления. Она характеризуется отсутствием типичных “экологических” рифов и представлена темноцветными (с повышенным содержанием керогена и микробиогенного пирита) пелитоморфными известняками (карбонатными черными сланцами). Фактически это карбонатные микробиогенные (при подчиненном участии макробиоты: криноидей, брахиопод) постройки, сформированные на депрессионном дне в условиях тесного взаимодействия углекислой и метановой, а также сероводородной глубинной дегазации. Были обнаружены фрагменты пиритизированных трубок иилиндрической и конусовидной формы, заполненных колломорфным, губчатым и фрамбоидальным пиритом, играющим большую роль в составе черных сланцев. По-видимому, это фрагменты микротрубчатой дегазационной системы, по которой в бассейн седиментации поступал глубинный сероводород. Отверстия в стенках трубок свидетельствуют о распылении двухфазного флюида на капли жидкости и пузырьки газа, при кавитации которых происходят микровзрывы, перфорирующие стенки трубок. Находка этих хрупких эфемерных образований, предположительно являющихся аналогами черных курильщиков, позволяет конкретизировать законо-

Цитування: Лукин А.Е. Ранневизейский эвксинский бассейн в системе Палеотетиса (в свете современных данных). Геологія і корисні копалини Світового океану. 2020. 16, № 2: 24-48. https://doi.org/10.15407/gpimo2020.02.024 
мерности накопления черносланцевых формаций эвксинского типа, что должно способствовать как освоению связанных с ними углеводородных и минеральных ресурсов, так и оценке их геоэкологического и эволюционно-биологического значения.

Ключевые слова: эвксинский бассейн, черные сланцы, сероводородная дегазация.

Общеизвестна уникальность Черного моря - крупнейшего на нашей планете сероводородного и метанового водоема, системной гидрологической, седиментационной, геохимической, биотической аномалии [8, 25, 27]. Изучение его различных аспектов связано с именами Г. Абиха, Н.И. Андрусова, А.Д. Архангельского, Н.М. Страхова, С.А. Ковалевского, М.В. Муратова, Г.И. Попова, П.В. Федорова, Л.А. Невесской, Е.Н. Невесского, Д.А. Туголесова, Л.Б. Мейснера, Ю.П. Непрочнова, А.В. Чекунова, В.А. Иванова, Г.Г. Поликарпова, М.В. Иванова, В.И. Сорокина, А.Ю. Леин, Л. Димитрова, Э. Дегенса, Д. Росса и др. В этой блестящей когорте особое место занимает Евгений Федорович Шнюков, целеустремлённые исследования которого охватили все аспекты данной уникальной природной геогенерационной модели - ключевой для изучения закономерностей влияния процессов глубинной дегазации Земли на седиментацию, осадочное рудообразование, нафтидогенез и экологию. Важнейшим направлением этих исследований является сравнительно-литологическое и литогеодинамическое изучение Черноморского бассейна и его древних разновозрастных аналогов. Среди последних особо выделяется удивительным сходством с Черным морем ранневизейский эвксинский палеобассейн, фрагменты которого приурочены к Днепровско-Донецкой впадине (ДДВ) и Придобруджинскому прогибу. Первые результаты его изучения (в сравнении с современным Черноморским бассейном) были опубликованы в конце XX - начале XXI столетия [10, 15]. В последние годы, в связи с появлением новых геолого-геофизических материалов и результатов электронно-микроскопических, рентгеноструктурных и геохимических исследований керна глубоких скважин, были получены новые данные формационного и литогеодинамического анализа нижневизейских черносланцевых формаций (гидрокарбопелитов) (Cneцифические по окраске и облику пелитоморфные, разнообразные по составу (широкие вариации соотношений органического, силикатно-глинистого, кремнеземного, карбонатного, фосфатного, сульфидного вещества) породы, которые в англоязычной литературе именуются "black shales”, а в отечественной - “черные сланцы” [29], целесообразнее именовать гидрокарбопелитами [9], что однозначно указывает на их главные черты: пелитоморфность и обогащенность сапропелевым - алиновым и амикагиновым в трактовке Н.Б. Вассоевича - органическим веществом $(\mathrm{OB}))$. Они, с одной стороны, подтвердили ранее полученные результаты, а с другой - существенно их дополнили. В связи с этим возникла целесообразность возвращения к указанной теме исследований в свете новых данных.

Выявление, картирование и комплексное изучение палеобассейнов эвксинского типа представляет первостепенный интерес с различных точек зрения.

Черносланцевые формации эвксинского типа относятся к наиболее специфическим геогенерациям (в понимании Н.Б. Вассоевича) наслоенной вулканогенно-осадочной оболочки земного шара - стратисферы. Они представляют особый интерес с точки зрения литогеодинамического и флюидодинамического анализа, поскольку в их генетических особенностях очень ярко проявляется взаимодействие экзогенных и эндогенных факторов седиментации. Особую роль 
эти формации играют в формировании нефтегазоносных бассейнов. Их наличие в том или ином интервале вертикального и латерального формационных рядов во многом определяет закономерности нефтегазонакопления, не говоря о том, что сами эти формации являются мегаловушками сланцевого, центральнобассейнового или “гибридного” газа $[14,17]$. Общеизвестна и их металлогеническая роль.

В теоретическом плане изучение закономерностей их образования определяется прежде всего тем, что черные сланцы (ЧС) эвксинского типа маркируют глобальные “бескислородные события” [31] на хроностратиграфических рубежах, с которыми связаны “скачки” макроэволюции и основные ароморфозы (в понимании А.С. Северцева) [7]. Часто они приурочены к переходным слоям, что необходимо учитывать при стратиграфической корреляции и формационной интерпретации сейсмических данных (сейсмостратиграфия, сейсмофациальный анализ). Кроме того, выявление и картирование “ископаемых” бассейнов черноморского типа является ключом к расшифровке геологического строения и закономерностей формирования сложных тектонических узлов и “коллажных” регионов, ярким примером которых является Азово-Черноморский регион.

Все сказанное в полной мере относится к объекту наших исследований. Помимо регионально-геологических, тектоно-геодинамических и нефтегазогеологических аспектов, его изучение имеет и более общее научное значение, поскольку, во-первых, речь идет о выделении нового хроностратиграфического уровня глобального “бескислородного события” [29], а, во-вторых, позволяет выделить достаточно древний и, в то же время, удивительно близкий по седиментационным, фациально-геохимическим и биотическим особенностям аналог эвксинского гидрокарбопелитового бассейна. Как это не парадоксально, охарактеризованный ниже ранневизейский бассейн был гораздо ближе по вышеуказанным показателям к голоценовому Черному морю, нежели многие общеизвестные мезозойские и кайнозойские эпизоды гидрокарбопелитового (в том числе и горючесланцевого) осадконакопления.

Глобальное значение этого визейского “бескислородного события” было обосновано автором в 1995 г. на ХІІІ Пермско-Карбоновом конгрессе в Кракове [34]. В частности, было показано присутствие гидрокарбопелитов эвксинского типа на данном стратиграфическом уровне, не фигурирующем в известных сводных работах по “черносланцевым” формациям, различных бассейнов Евразии и Северной Америки.

Наиболее полное проявление данного события (при высокой степени геолого-геофизической, седиментологической, геохимической, палеоэкологической изученности) связано с центральной частью ДДВ. Здесь уместно отметить, что раннекаменноугольная история Днепровско-Донецкого тектонотипа континентальных рифтогенов длительное время трактовалась весьма упрощенно - на основе простой экстраполяции данных по разрезам периферийных зон, крупных поднятий и выступов на слабо освещенные глубоким бурением центральные части, включая наиболее погруженную приосевую зону. Поэтому раннекарбоновый этап развития Днепровско-Донецкого авлакогена (ДДА) длительное время рассматривался (некоторыми исследователями - вплоть до настоящего времени) как своего рода “тектоно-геодинамическая пауза”, наступившая после девонского рифтогенеза (с интенсивным вулканизмом и соленакоплением) и характеризующаяся шельфовым (в палеотектоническом смысле) терригенным (кварцевые 
песчаники, каолиновые глины и т.п.) и карбонатным осадконакоплением. Однако еще 40 лет назад было показано, что нижний карбон ДДВ и Донбасса характеризуется четкой формационной зональностью, в соответствии с которой шельфовые терригенные и карбонатные отложения сменяются в погруженных частях ДДА, обрамленных барьерными рифами и подводнооползневыми блоками, мощными депрессионными флишоидными отложениями с широким развитием турбидитов и контуритов, разнообразных гидрокарбопелитов, а также других специфических литогеодинамических индикаторов [19]. Эта тектоно-формационная особенность нижнего карбона ДДА в полной мере свойственна его трем ярусам турнейскому, визейскому и серпуховскому. В частности, нижневизейский подъярус, основная часть которого не имеет аналогов в стратотипических разрезах (табл. 1), в центральной части ДДВ отличается от платформенных разрезов огромными (до 1,5-2 км) мощностями и уникальной стратиграфической полнотой.

Говоря об удивительном сходстве Черноморского голоценового и Придобруджинско-Днепровско-Донецкого ранневизейского (ХІІа м.ф.г.) седиментационных бассейнов, целесообразно отметить существенные различия той структурно-формационной “рамы”, которая подстилает соответствующие гидрокарбопелитовые формации. В обоих случаях в ее составе ведущую роль играют рифогенно-карбонатные комплексы (РКК). Однако, если в составе РКК Азово-Черноморского региона (палеоцен, верхний мел, верхняя юра) присутствуют типичные “экологические рифы” с характерным набором фаций, то ранневизейское и турнейское карбонатонакопление ДДВ и Придобруджинского прогиба весьма специфично. Оно отличается отсутствием типичных “экологических рифов”: биокарбонатных каркасных и (или) каркасно-аккумулятивных сооружений и продуктов их волнового разрушения (парагенез собственно рифа, предрифового

Таблица 1. Нижневизейские стратоны

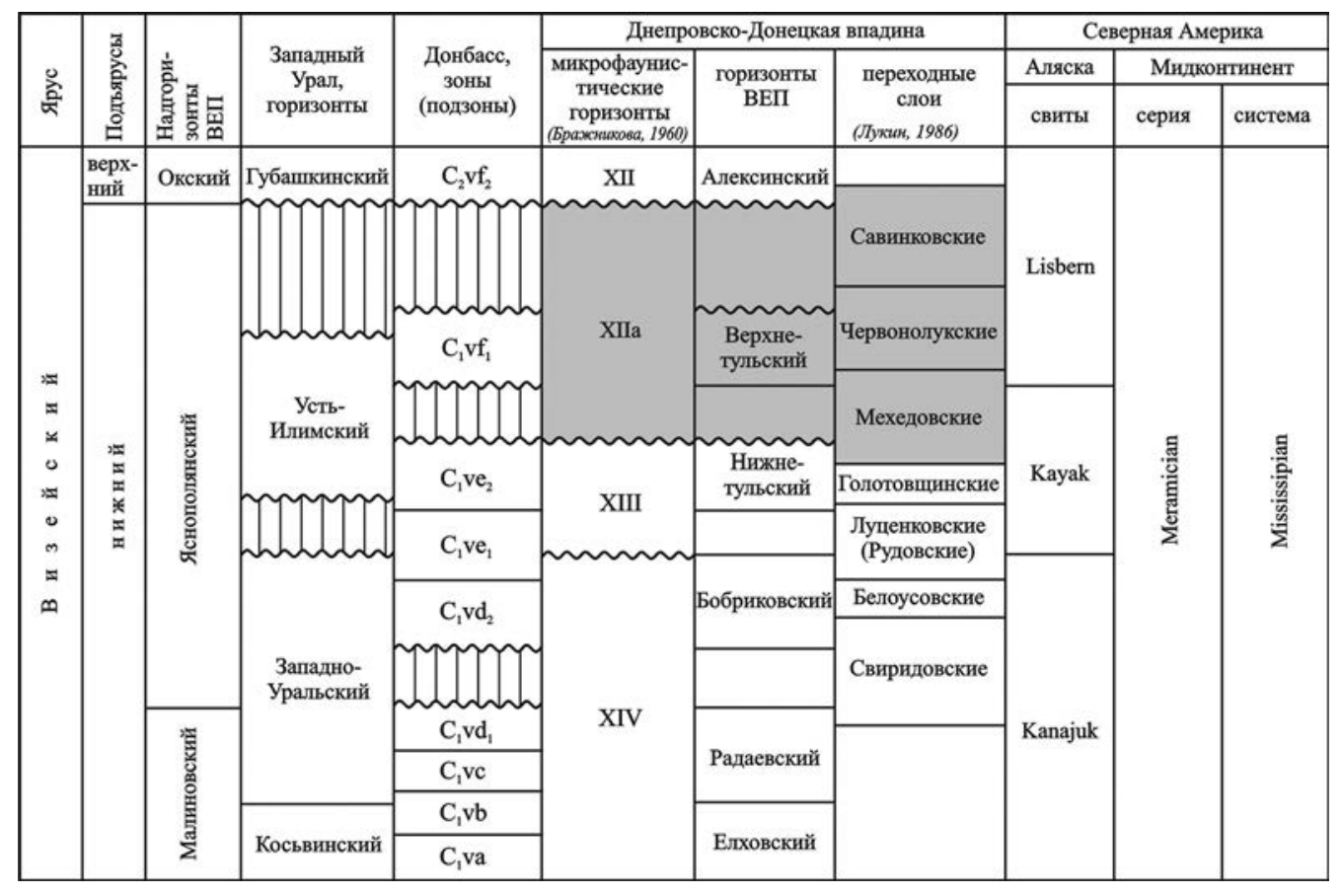



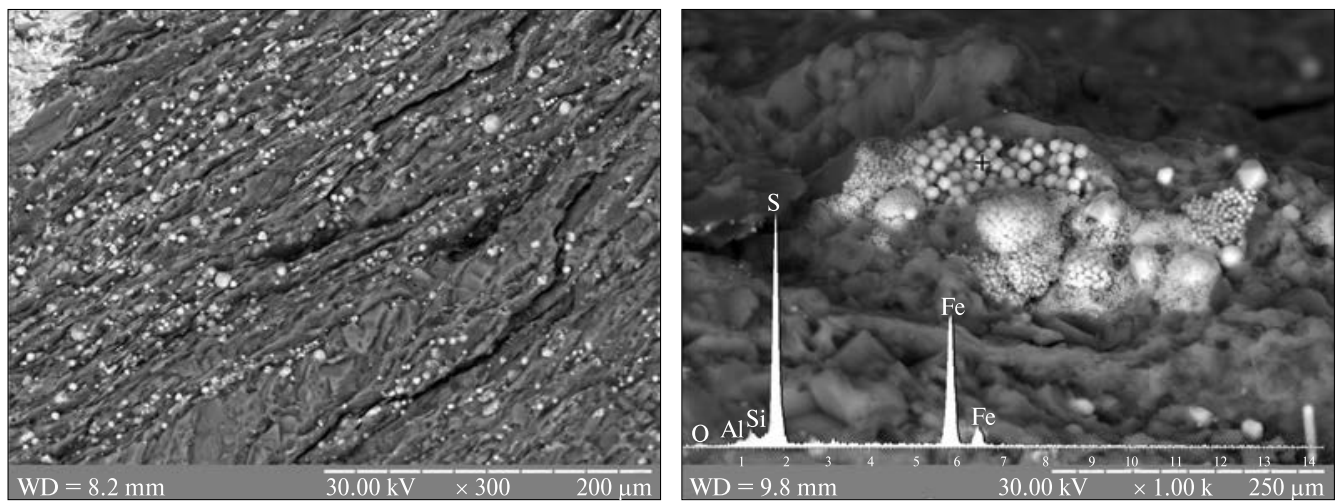

Puc. 1. Микробиогенная пиритизация в нижневизейском черном микритовом известняке (ДДВ, скв. 17-Семиренковская, инт. 5974,5-5980,58 м)

шлейфа и зарифовых отложений), изначально обладающих высокими коллекторскими свойствами.

В Западной Европе и Северной Америке РКК нижнего карбона представлены т.н. уолсортскими (Waulsortian) фациями, хорошо изученными по обнажениям и данным неглубокого бурения на территории Бельгии (именно по названию деревни Уолсорт в динантском бассейне Бельгии данный фациальный комплекс и был выделен свыше 150 лет назад Э. Дюпоном в качестве “уолсортских слоев” “Assise de Waulsort” [33]), Центральной Франции, Англии, Ирландии, США (Оклахома, Монтана, Техас, Нью-Мексико) и Канады (Альберта). Вместо типичных рифов здесь присутствуют куполовидные карбонатные тела (уолсортские карбонатные купола), которые также получили наименование иловых холмов (mud mounds) [24]. Размеры их в поперечнике варьируют от нескольких сотен метров до 2-3 км и более, а высота над дном морского палеобассейна - от первых десятков до нескольких сотен метров.

Степень выраженности куполоподобной формы зависит от палеотектонической позиции. В шельфовых зонах турнейско-визейских (динантских, миссисипских) морских бассейнов это уплощенные тела, а в их обширных депрессионных областях - четко выраженные купола с градиентом толщин свыше 100-200 м на 1,5-2 км. Они сложены массивными пелитоморфными (микритовыми) темноцветными известняками, остатки макробиоты которых представлены разнообразными по величине и биоструктуре фрагментами криноидей, а также колониальных мшанок-фенестелид. На склонах уолсортских куполов (иловых холмов) локализуются брахиоподовые банки.

В отличие от рифовых сооружений других РКК, уолсортские купола представляют собой темноокрашенные массивные пелитоморфные плотные малопроницаемые образования, которые можно отнести к ЧС. Их литологические, наномикроструктурные и геохимические особенности свидетельствуют о микробиогенной природе матрикса иловых холмов, что согласуется с обилием фоссилизированных пиритом сульфатредуцирующих бактерий (рис. 1).

Об интенсивных анаэробных микробиогенных процессах свидетельствует также резко облегченный состав сульфидной $\left({ }^{34} \mathrm{~S}_{\text {пир. }}\right)$ и органической $\left({ }^{34} \mathrm{~S}_{\text {орг }}\right.$. серы, в то время как зарифовые фации силурийских, девонских, пермских РКК характеризуются изотопно-тяжелой сульфатной серой $[8,9,15]$. 

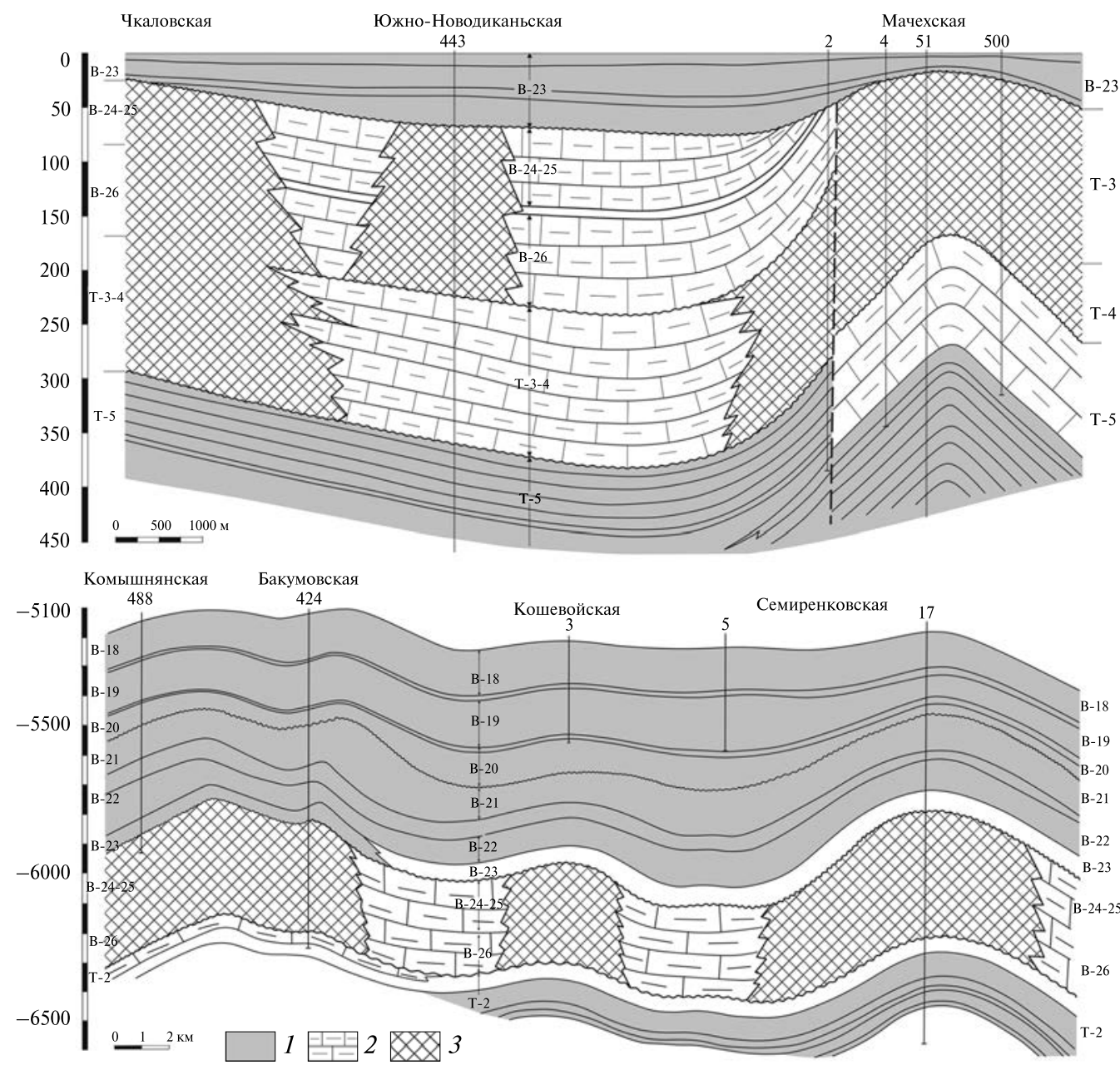

Puc. 2. Литолого-палеотектонические разрезы турнейско-нижневизейских отложений центральной части ДДВ [18]: 1 - полифациальные карбонатно-терригенные отложения; 2 - карбонатно-глинистые отложения, доманикоиды; 3 - уолсортские купола

Ведущая роль анаэробно-бактериальных процессов в формировании микритового карбонатного вещества уолсортских куполов объясняет механизмы скрепления иловых частиц (и фрагментов микробиоты) и ранней литификации уолсортских куполов (несмотря на относительную глубоководность и связь с депрессионно-морскими условиями). Биокарбонатная природа уолсортских куполов позволяет рассматривать их как гомолог карбонатных органогенных построек в типичных палеозойских и мезозойских РКК. Вместе с тем, коренным отличием уолсортских куполов от рифовых построек других РКК является, как отмечалось, полное отсутствие первичных коллекторских свойств. Эти плотные темноокрашенные (за счет дисперсного $\mathrm{FeS}_{2}$ и $\mathrm{S}$-содержащего $\mathrm{OB}$ ) породы отличаются от биоморфных известняков девонских, среднекаменноугольных, нижнепермских, мезозойских и, тем более, кайнозойских РКК высокими прочностными свойствами.

В практике геологоразведочных работ в ДДВ, в частности, укоренилось представление о “визейской плите” как о региональной малопроницаемой толще 

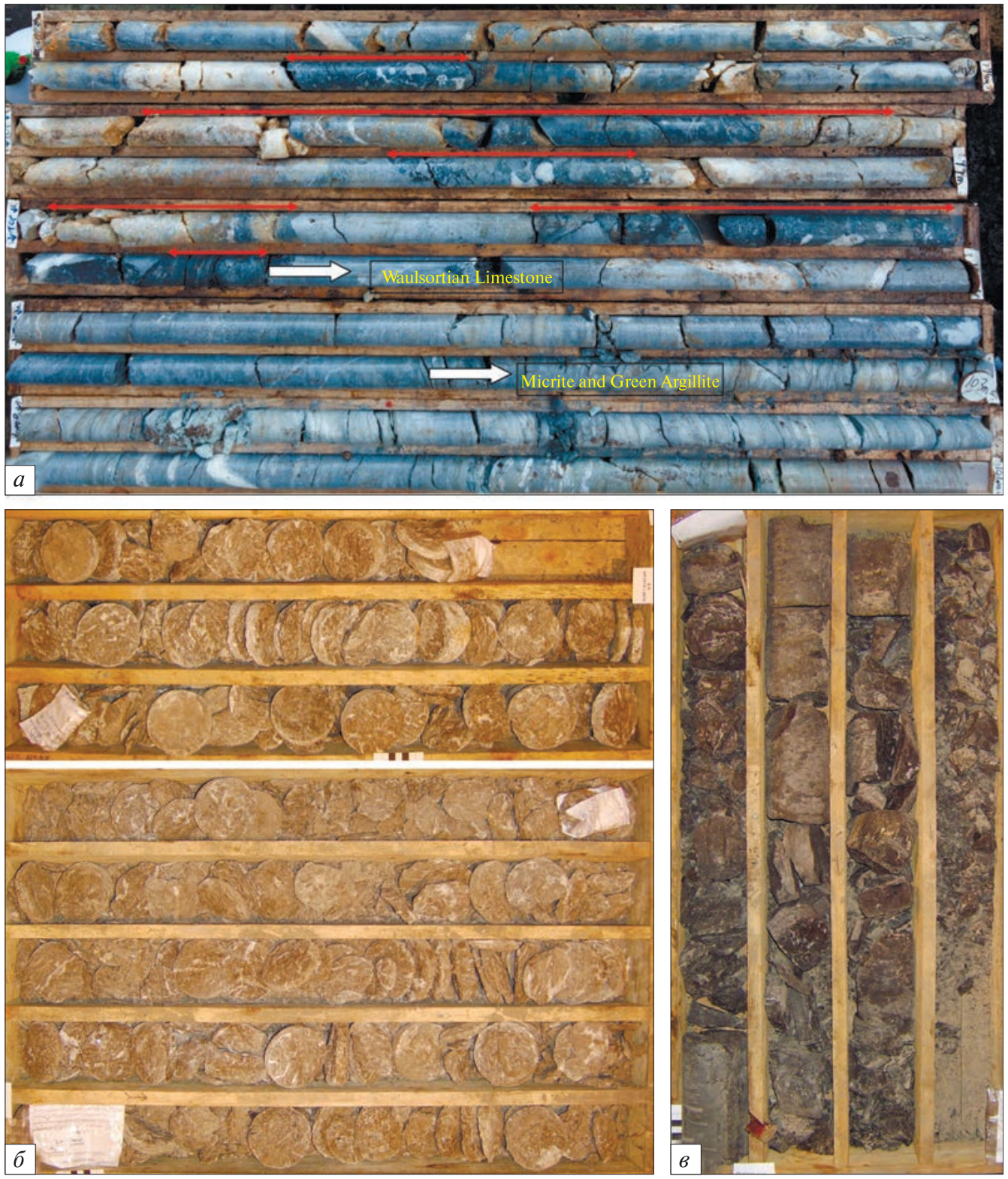

Puc. 3. Различная степень саморазрушения керна карбонатных пород уолсортских куполов в зависимости от глубины залегания: $a$ - отложения верхнего динанта Ирландии Tulla Licences, интервал глубин 85-106 м [31]; б - ДДВ, скв. 17-Семиренковская, интервал глубин 6186,16193,6 м [18]; в - ДДВ, скв. 17-Семиренковская, интервал глубин 6210,4-6216,3 м [18]

плотных темноцветных кремнисто-карбонатных отложений. Однако, данные глубокого бурения и сейсморазведки позволили установить ее гетерогенный характер. В частности, в приосевой зоне ДДВ она представляет собой мозаику большого количества микритовых куполов (иловых холмов), залегающих среди депрессионных отложений, представленных глинисто-кремнисто-карбонатными доманикоидами (гидрокарбопелитами) (рис. 2). При этом уолсортские купола обнаруживают четкую связь с погребенными палеоподнятиями, к которым 
приурочены месторождения с залегающими на глубинах более 4-5 км газоконденсатными (реже - нефтяными и гетерофазными) залежами в полифациальных преимущественно терригенных верхневизейских отложениях (продуктивные горизонты В-18 $\div$ В-23).

Несмотря на отсутствие достаточно целенаправленных поисков нефтяных и газовых залежей в рифогенно-карбонатных ловушках (степень освоения их углеводородного потенциала в нефтегазоносных регионах Украины по сравнению с терригенными комплексами невелика), был открыт ряд месторождений с нефтяными и газоконденсатными залежами именно в турнейских и нижневизейских РКК (Богатойское, Кампанское, Мачехское, Новониколаевское, Селюховское, Беличевское и др.). Субстратом формирования этих вторичных коллекторов являются уолсортские фации. Основным фактором их формирования является разноориентированная открытая (микро)трещиноватость, интенсивность которой возрастает с глубиной. Отмечено несколько уровней ее увеличения, приуроченных к глубинам 3,5-3,8; 4-4,5; 5-5,5; 6-6,5 км. На глубине свыше 6,5 км, судя по данным бурения сверхглубокой скв. 17-Семиренковской, при подъеме керна нижневизейских карбонатов наблюдается их “саморазрушение”, свидетельствующее о высоком внутрипоровом давлении и газонасыщенности (рис. 3). Таким образом происходит трансформация плотных уолсортских “иловых холмов” в разуплотненные тела. Уолсортский купол (плотный “иловый холм”) превращается в природный резервуар углеводородного флюида, фазовое состояние которого определяется конкретными геотермобарическими условиями (на глубинах свыше 5 км это преимущественно разнообразные газоконденсатные системы). Данные изучения морфологии трещин свидетельствуют о взаимодействии сжимающих и растягивающих радиальных и тангенциальных напряжений. Этот сложный геодинамический режим трещинообразования, по-видимому, лишь частично связан с тектоническими факторами (активизация сдвиговых смещений на нео- и актуотектоническом этапах). Главной же причиной такого импульсного (квазиэксплозивного) разуплотнения уолсортских куполов является, как уже отмечалось [12], физико-химическая трансформация в условиях повышенных температур и давлений. Это результат взаимодействия ряда факторов, главными из которых являются: а) стягивание тектонических напряжений на залегающие в анизотропной слоисто-зональной среде первоначально весьма прочные (по сравнению с вмещающими отложениями) куполообразные тела; б) гидротермолиз керогена и гидрофобизация матрицы; в) водородная продувка и углеводородная накачка в формирующийся гидрофобный трещинный коллектор [11-13].

Геолого-геофизические данные и результаты литолого-палеогеографического картирования турнейских и нижневизейских отложений свидетельствуют о широком распространении уолсортских куполов в пределах обширной депрессионной области морского турнейско-ранневизейского бассейна, фрагмент которого показан на рис. 4. Данные глубокого бурения на Семиренковском, Камышнянском, Мачехском, Яблуновском и других месторождениях центрального сегмента ДДВ позволяют предположить их присутствие на многих погребенных локальных структурах - древних палеоподнятиях.

Породы уолсортских фаций в условиях залегания на небольших и средних глубинах представляют собой ЧС (black shales) существенно карбонатного состава. При их физико-химической, тектоно- и флюидодинамической активизации 


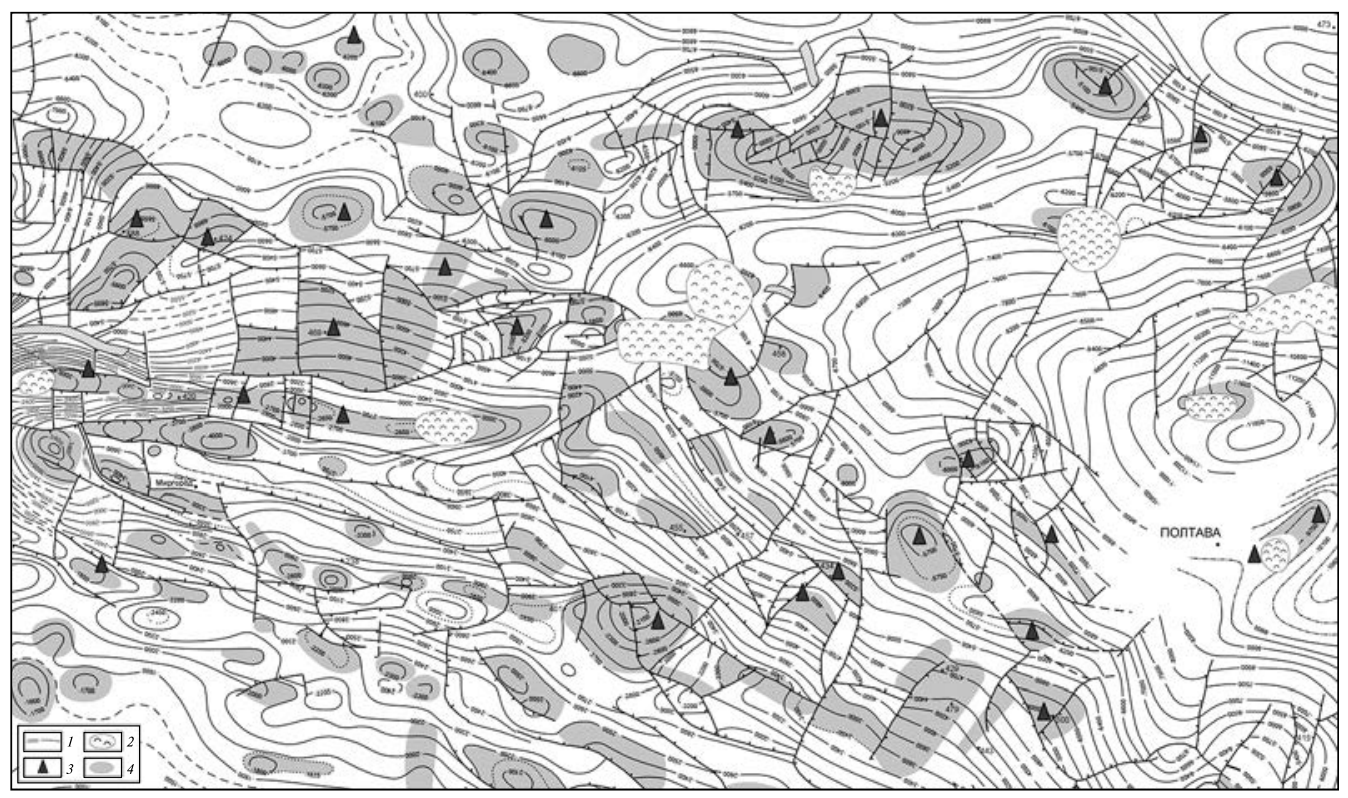

Puc. 4. Перспективы нефтегазоносности уолсортских куполов центральной части ДДВ на глубинах более 5 км [18]: 1 - изогипсы отражающего горизонта $\mathrm{VB}_{2-п}$ (по данным сейсморазведки МОГТ); 2 - соляные штоки; 3 - месторождения с газоконденсатными залежами на глубинах более 5 км; 4 - участки локализации уолсортских куполов

они превращаются в резервуары залежей традиционного типа. Это позволяет рассматривать месторождения центральной части ДДВ, характеризующиеся большим стратиграфическим, глубинным и фазово-геохимическим диапазоном, как своего рода гибридные углеводородные системы, для эффективного освоения которых (комплексная разработка залежей традиционного и нетрадиционного типов) необходимо применение новых методов.

Особого внимания заслуживает возможно высокая гелиеносность газов глубокозалегающих уолсортских фаций в ДДВ, о чем свидетельствует аномально высокое (1,78 \% мас.с или 10,72 \% мольн.), существенно превышающее модальные концентрации Не за счет генерации их радиоактивными элементами (U, Th) вмещающих депрессионных фаций, содержание Не в пробе водорастворенного газа, отобранной из карбонатных коллекторов нижнего визе на Светличном месторождении. При этом есть основания предполагать повышенную роль мантийного гелия и в перспективе рассматривать глубокозалегающие нижневизейские депрессионные отложения центральной части ДДВ как возможный источник изотопа ${ }^{3} \mathrm{He}$.

Таким образом, нижневизейские и турнейские РКК характеризуются признаками эвксинской седиментации, которая ярко проявляется в вышележащих отложениях (ХІІа м.ф. горизонт, рудовские слои).

Собственно нижневизейская черносланцевая формация представлена толщей (600-1200 м и более) темноцветных глинистых пород с терригенными отложениями мутьевых потоков (турбидиты), контурных течений (контуриты) и разнообразных аккумулятивных песчаных тел - выносов рек и подводных течений (в халистазы), а также подводных оползней [9, 15]. Роль песчаников возрастает вверх по разрезу. Эти седиментационно-палеогеоморфологические формы, кото- 
рые образуют разнообразные морфогенетические типы ловушек углеводородов, с различной степенью четкости выделяются на временных разрезах, сейсмофациальные особенности которых в целом характерны для клиноформенного заполнения глубоководных депрессионных бассейнов. Черные (буровато-черные, темно-серые) пелитоморфные породы характеризуются: а) широкими вариациями соотношений ОВ с глинистым, а также кремнеземным, карбонатным и фосфатным материалом; б) микрослоистыми текстурами (при отсутствии биотурбаций); в) специфической биотой. Последняя, помимо углефицированных растительных детритусово-шламовых остатков, представлена спорадически распространенной специфической фауной остракод, лингул, планктонных фораминифер, мелких брахиопод, спикул губок, радиолярий и др. Это типичный депрессионный комплекс, присущий относительно глубоководным бассейнам с определенными нарушениями газового режима, которые обусловлены углекисло-сероводородным заражением и интенсивной метановой газоотдачей дна. В основании разреза данного стратона (формально - верхнетульского подгоризонта Унифицированной схемы Восточно-Европейской платформы, фактически - совокупности слоев переходного характера, не имеющих платформенных аналогов) присутствует пачка (до 10 м) темноцветных окремнелых радиоляриево-спикуловых микрозернисто-шламовых известняков, спонголитов, радиоляритов с фосфатными нодулярными стяжениями. Она отвечает максимально глубоководной фазе развития эвксинского бассейна. Присутствие в составе пород базальной пачки аутигенной анальцимовой минерализации (по данным электронной микроскопии и рентгеноструктурного анализа) и геохимические особенности (повышенные концентрации бора, ртути, бария, ванадия, свинца и др.) свидетельствуют о том, что она соответствует и фазе максимальной конседиментационной эндогенной активности [15]. Вышележащая темноцветная глинистая пачка (до 50 м) отличается преобладанием высокоуглеродистых пород - типичных гидрокарбопелитов $\left(\mathrm{C}_{\text {орг }} 4-10 \%\right.$ и более), которые, с учетом катагенетических потерь ОВ (глубины залегания свыше 4,5-5 км, градации катагенеза по цветовому индексу спор MK1-MK4, палеотемпературы 90-230 ${ }^{\circ} \mathrm{C}$ ), представляли собой на стадии протокатагенеза горючие сланцы, а на стадиях седиментогенеза и диагенеза - сапропелевые илы с исходным содержанием ОВ до 20-30 \% и выше [15]. Мощная радиоактивная аномалия, приуроченная к двум этим пачкам на диаграммах гамма-каротажа, связана с аномально высоким содержанием урана (60-100 г/т) и тория (30-60 г/т). Это межрегиональный радиоактивный репер. Присутствие его “хвостов” в кровле обрамляющих палеодепрессию рифов свидетельствует о том, что накопление этих радиоактивных глин знаменовало прекращение в бассейне морского биокарбонатонакопления (исчезновение криноидей, мшанок, брахиопод). В середине и кровле пачки отмечены песчаные слои, которые, судя по наличию градационной слоистости, основным структурно-гранулометрическим параметрам и особенностям вещественного состава относятся к турбидитам. Кроме того, в нижней части разреза установлено присутствие еще двух аналогичных по литологическим и геохимическим особенностям, близких по мощностям и строению гидрокарбопелитовых пачек. Их совокупность образует характерную группу промыслово-геофизических реперов, позволяющих коррелировать разрезы данного стратона не только в пределах ДДВ, но и межрегионально (рис. 5). При этом особого внимания заслуживает присутствие уцелевшего в пределах 


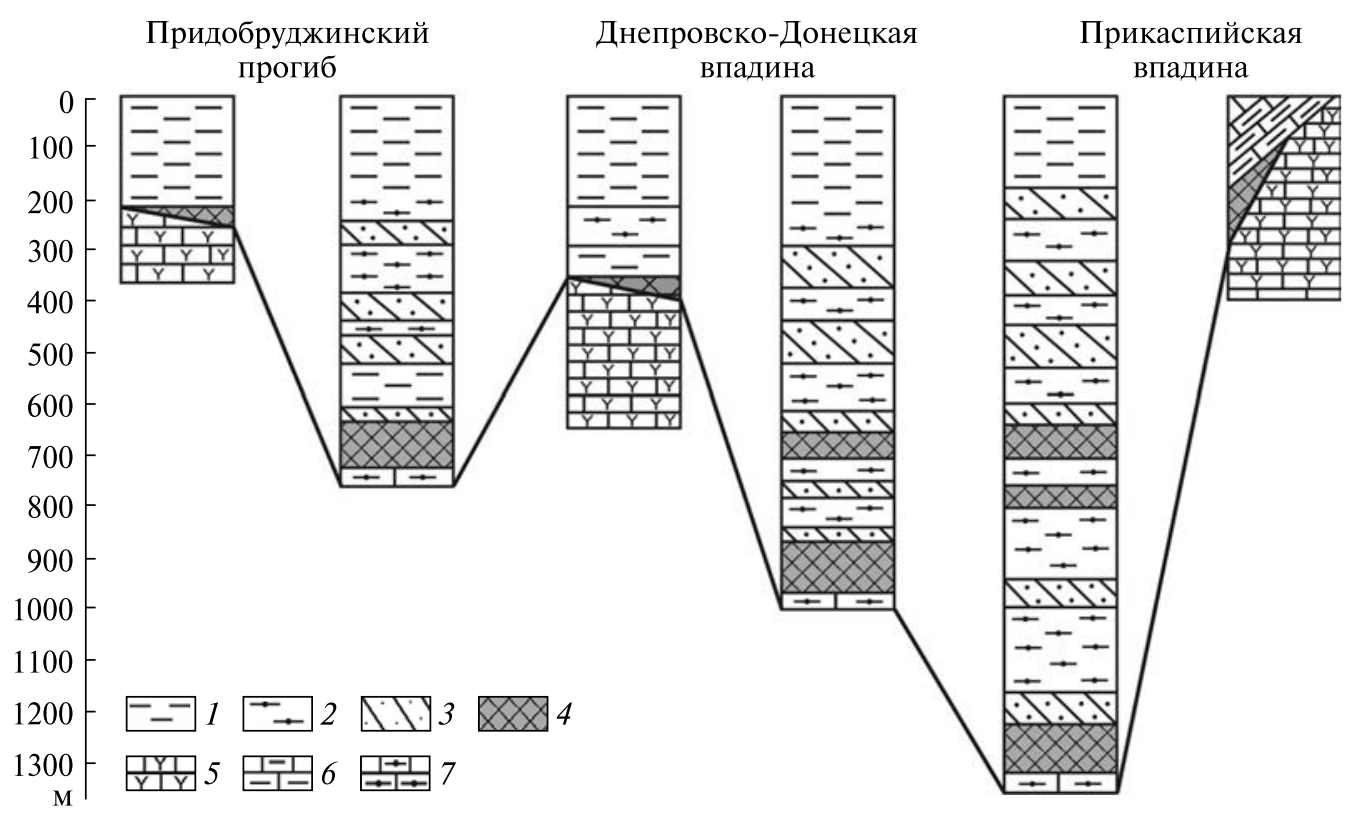

Puc. 5. Схема межрегиональной корреляции нижневизейских гидрокарбопелитовых отложений: 1 - темноцветные глинистые породы; 2 - гидрокарбопелиты с окремнением и пиритизацией; 3 - турбидиты; 4 - гидрокарбопелиты с максимальным содержанием ОВ (первоначально-сапропелевые илы); 5 - рифовые известняки; 6 - глинистые известняки; 7 - окремнелые известняки

Белолесского блока Придобруджинского прогиба при грандиозном предпозднепермском (предпермотриасовом) размыве дислоцированных среднепалеозойских отложений эрозионного останца нижней части ранневизейских отложений (аналогов ХІІа м.ф. горизонта) с весьма сходной литомной ассоциацией. Это свидетельствует о существовании единого Придобруджинско-Днепровско-Донецкого ранневизейского бассейна эвксинского типа (рис. 6).

Основная по объему вышележащая часть, как уже отмечалось, характеризуется резким повышением роли песчаных тел. Среди них преобладают турбидиты, отмечено присутствие контуритов, а в периферийных частях бассейна появляются, смещаясь по мере осадконакопления к приосевой зоне, подводные выносы рек, аккумулятивные тела типа устьевых баров и т.п. (рис. 7).

Глинистые отложения этой части разреза представлены хорошо отмученными аргиллитами. Это типичные "black shales" (содержание $\mathrm{C}_{\text {орг }} 1,5-4,5 \%$ ) с неравномерно распределенной специфической биотой (планктонные фораминиферы, конодонты, ихтиодетрит, карликовые брахиоподы, тонкостенные пелициподы, разнообразные растительные остатки, включая обильные споро-пыльцевые комплексы). Все ранневизейские глинистые отложения характеризуются общими литологическими, геохимическими и палеоэкологическими особенностями несмотря на широкие вариации соотношений между органическим, глинистым, кремнеземным, Fе-(ди)сульфидным и фосфатным веществом. Они представляют собой темноокрашенные (черные, темно-серые, черно-коричневые) пелитоморфные микрослоистые породы. Их выраженная с различной степенью четкости микрослоистая текстура обусловлена распределением ОВ, органичес- 
Puc. 6. Ранневизейские бассейны эвксинского типа системы Палеотетиса. Палеогеодинамическая схема

ких остатков, пиритизацией, окремнением. Биота, как уже отмечалось выше, носит специфический характер. Характерные для визейских морских фаций различных регионов Европы и Северной Америки банки разнообразных брахиопод (спириферид, продуктид и др.), заросли криноидей, кораллы, водоросли и т.п., здесь отсутствуют. Ассоциация фораминифер очень обеднена и представле-

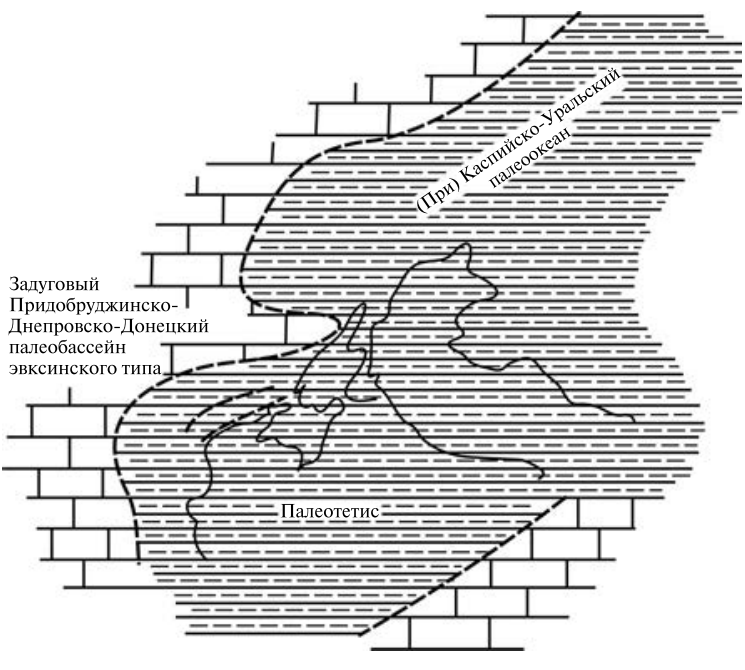
на только планктонными формами. Фауна остракод, двустворок, лингул, мшанок, радиолярий, губок встречается спорадически и носит явно депрессионный характер. Растительные остатки (детрит, шлам, обильные споры и др.), ихтиодетрит, конодонты приурочены к раз-

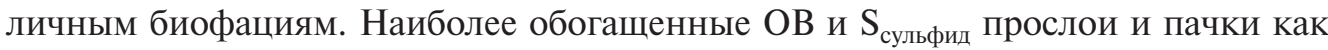
правило не содержат макрофаунистических остатков. Кроме того, наблюдается определенная связь распределения различных окаменелостей и углефицированных растительных остатков с турбидитами.

Общее содержание остаточного ОВ варьирует от 2,5-5 до $12-14 \%$, что соответствует уровню его концентрации в таких верхнеюрских гидрокарбопелитах как бажениты (Западная Сибирь) и "hot shales" (Североморская впадина), залегающих на значительно (2-3 км) меньших глубинах в гораздо более молодых (на $\sim 200$ млн лет) отложениях. Первоначальное содержание ОВ в ранневизейских эвксинитах с учетом катагенетических потерь вполне соответствует уровню его содержания в кайнозойских эвксинитах. Подобно им, кероген рассматриваемых отложений характеризуется смешанным сапропелево-гумусовым составом при большой роли растительного шлама, обрывков ксилемы, споро-пыльцевого материала, кутинита и др. Присутствие обильной фоссилизированной микробиоты (пиритизированные колонии сульфатредуцирующих метанотрофных бактерий и др.) по данным электронномикроскопического изучения позволяют предположить существенно бактериальную природу сапропелевой части ОВ.

По значениям $\delta^{13} \mathrm{C}_{\text {орг }}(-27 \div-28,5 \%$ ) ранневизейские гидрокарбопелиты близки нижнемеловым black shales Атлантического океана и верхнеюрским баженитам Западной Сибири. $\delta \mathrm{D}_{\text {орг }}$ варьирует в пределах $-112 \div-115 \%$ \% $\left(\delta \mathrm{D}_{\text {орг }}\right.$ баженитов по нашим данным составляет $-105 \div-108 \%$ ). Валовое содержание хлороформенного битума в породах находится в пределах $0,016-0,35$ \% (с содержанием масел $37-55 \%$ ), достигая максимальных значений в наиболее обогащенных ОВ пачках - радиоактивных реперах нижней части разреза. По сравнению с обычными нижнекарбоновыми глинами (аргиллитами) ранневизейские black shales характеризуются: а) резко повышенным содержанием всех типов битумоидов и хлороформенного битума (до $0,8 \%$ ); б) высоким содержанием адсорбированного метана и более тяжелых углеводородов; в) сложным сероводородно- 


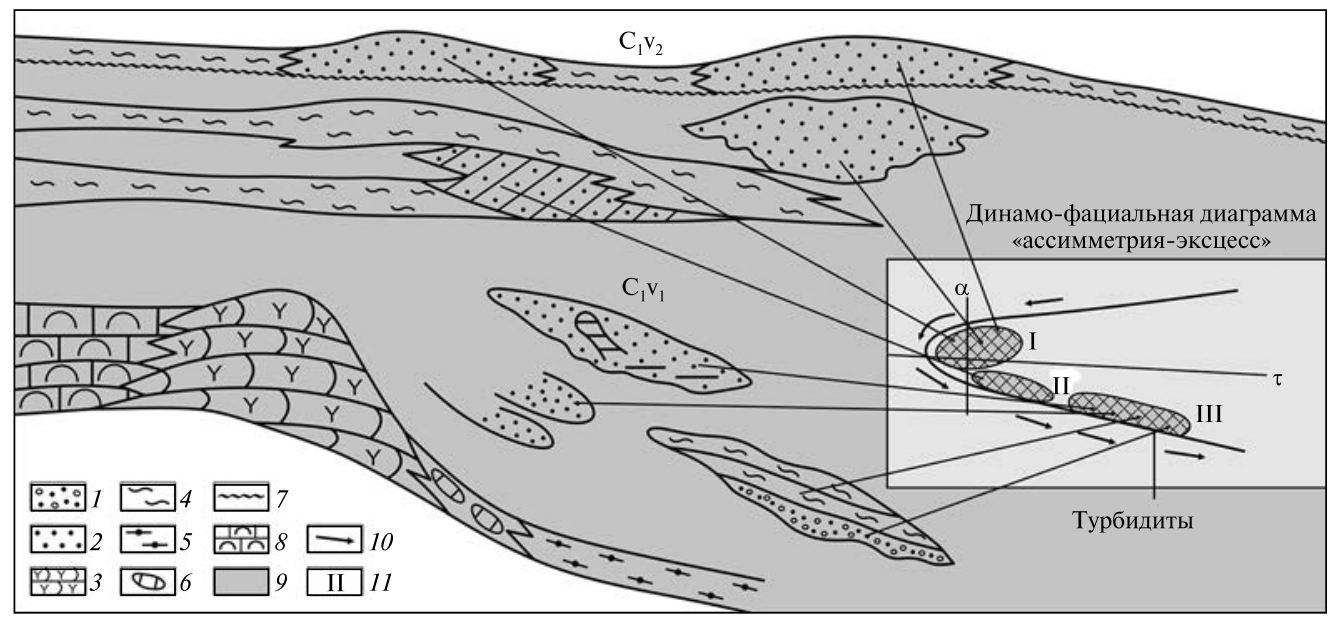

Puc. 7. Парагенезис различных фациальных типов песчаных тел в нижневизейских отложениях Днепровско-Донецкой впадины: 1 - гравелиты; 2 - песчаники; 3 - биоморфные известняки; 4 - алевролиты; 5 - окременелые микрозернистые битуминозные известняки и гидрокарбопелиты; 6 - предрифовый шлейф; 7 - поверхность предпоздневизейского (предокского) несогласия; 8 - органогенно-детритусовые известняки; 9 - гидрокарбопелиты (black shales); 10 направление уменьшения степени сортировки обломочного материала; 11 - фациальные обстановки: I - морская, II - дельтовая, III - контурит-турбидит-подводнооползневая

азотно-водородно-углеводородным составом газов закрытых пор (метан 10-60 \%, тяжелые углеводороды 5-25\%, $\mathrm{H}_{2} 5-50 \%, \mathrm{~N}_{2} 18-45 \% ; \mathrm{H}_{2} \mathrm{~S} 1-15 \%$ ) $[15,17]$.

В связи с вышеуказанными изотопно-геохимическими особенностями большой интерес представляют спорадические карбонатные образования (в ассоциации с проблематичными трубчатыми формами и пузырьковыми отпечатками) с облегченным изотопным составом углерода (рис. 8). Эта седиментационно-раннедиагенетическая кальцитовая (первоначально, по-видимому, арагонитовая) минерализация, очевидно, связана с хемосинтетическими экосистемами, сопутствующими метановым сипам и курильщикам (см. ниже). Кроме того, вполне вероятна и карбонатообразующая роль продуктов анаэробного окисления метаново-газогидратных скоплений.

Минеральные особенности глинистого вещества ранневизейских гидрокарбопелитов (смесь гидратированных гидрослюд, смешаннослойных фаз типа слюда-монтмориллонит, несовершенного моноклинного каолинита и др.) свидетельствуют о смешанном происхождении. Основная его масса образовалась за счет терригенного материала, который, судя по трансформации исходного триклинного совершенного каолинита из гумидных кор выветривания (центральные районы Украинского щита и Воронежского массива) и гидратации гидрослюд, подвергался интенсивной деградации в агрессивной среде придонных и иловых вод со специфическим газовым и гидрохимическим режимом, обусловленным интенсивными анаэробными процессами и гидротермальными эксгаляциями [9]. Формирование смешаннослойных минералов (точнее - органоминеральных фаз) было связано с процессами синтеза из гелей (продуктов эксгаляций и гальмиролиза вулканического пепла). Прямым доказательством присутствия в седиментационном фонде “камуфлированного” вулканического и эксгаляционного 


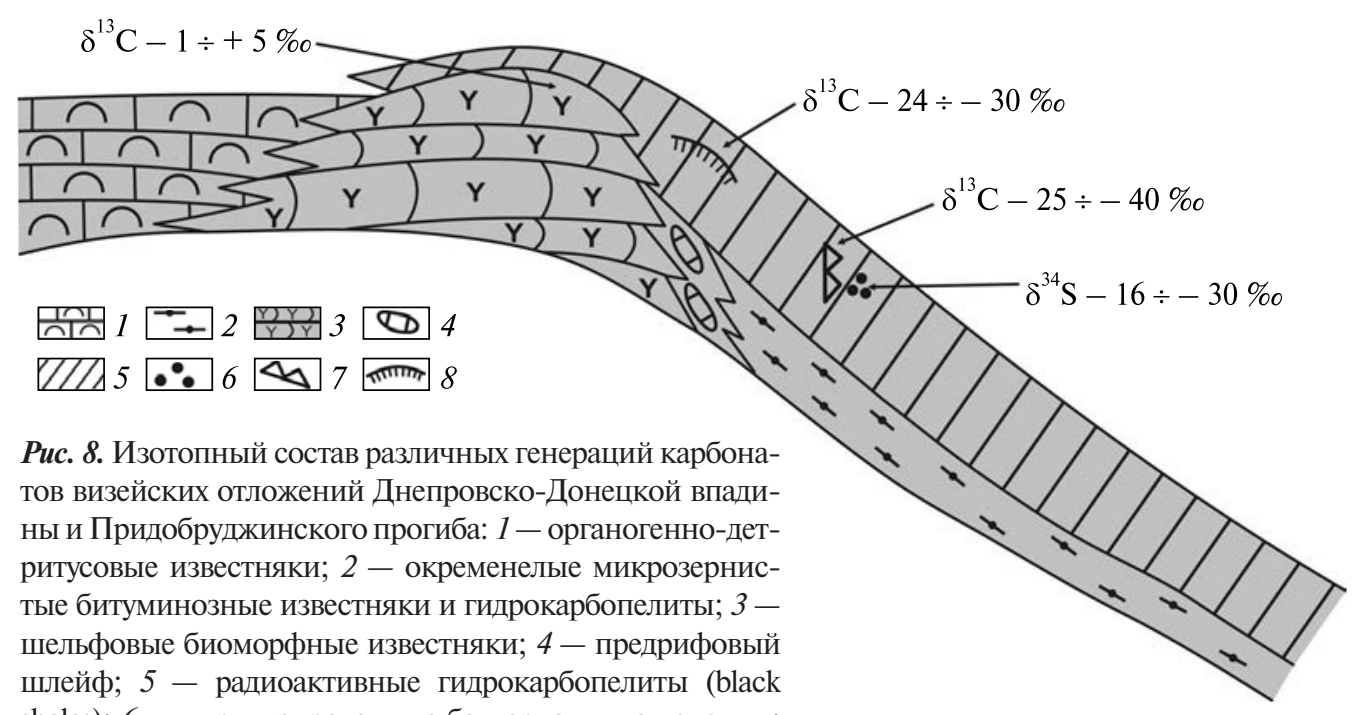
shales); 6 - пиритизированные бактериальные колонии; 7- реликты известковых корок, связанных с разрушением газогидратных скоплений; 8 - реликты известковых бактериальных матов (индикаторов метановых сипов)

материала являются реликты пепловой структуры и цеолитовая (анальцим, сколецит и др.) минерализация [15].

В целом эта формация, как уже неоднократно отмечалось, по своему строению, мощностям и скоростям седиментации поразительно (с учетом колоссальной возрастной дистанции, коренных историко-геологических и биотических различий) близка голоценовым отложениям Черного моря (рис. 9). Особенно следует подчеркнуть сходство в распределении гидрокарбопелитовых пачек (первоначально сапропелевых илов) и единство их седиментационной природы. Геохимические особенности ОВ голоценовых черноморских илов [2] и ранневизейских придобруджинско-днепровско-донецких гидрокарбопелитов $[8,9]$ очень близки. Это относится также к минеральным особенностям глинистого вещества, концентрациям халькофильных и сидерофильных элементов. Главное же заключается в принципиальной генетической общности сапропелевых осадков обоих бассейнов. Преимущественно бактериальный характер их ОВ обусловлен интенсивными процессами бактериального хемосинтеза (сопряженность процессов метаноокисления и сульфатредукции), которым благоприятствовали свойственные эвксинским бассейнам геоморфологические, гидрологические особенности, а также аномально высокая газоотдача $\left(\mathrm{CH}_{4}, \mathrm{CO}_{2}, \mathrm{H}_{2} \mathrm{~S}, \mathrm{H}_{2}\right)$ дна.

В структуре седиментационного фонда обогащенных сапропелевым и смешанным (гумусово-сапропелевым) ОВ ЧС (доманикиты и доманикоиды, бажениты и другие древние аналоги эвксинитов) велика роль эндогенного осадочного материала [9]. Именно эндофонд в значительной мере определяет соотношение филлосиликатного, кремнеземного, карбонатного, Fe-(ди)сульфидного, фосфатного и ОВ в их составе и геохимические особенности [9, 15]. Однако конкретные “механизмы” реализации эндогенных факторов указанных формаций недостаточно изучены. В тектоно-геодинамическом отношении они представляют собой отложения относительно глубоководных котловинных морских 


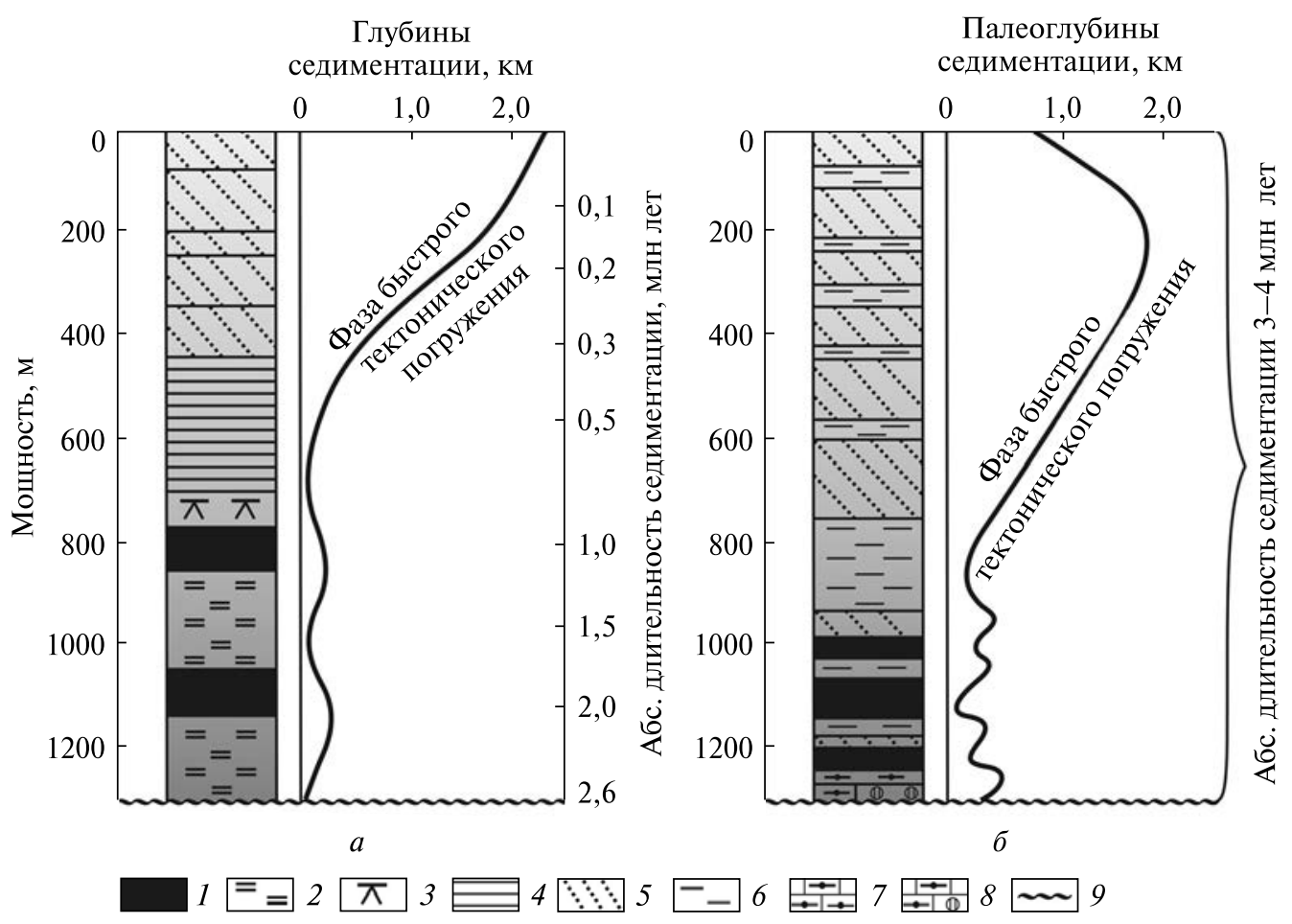

Puc. 9. Сравнение закономерностей седиментации голоценового и раннекарбонового эвксинских бассейнов с высокой газоотдачей дна: $a-$ Черное море (по Е. Дегенсу и др., с изменениями), б - нижневизейский Придобруджинско-Днепровско-Донецкий палеобассейн (по А.Е. Лукину [15]). 1 - сапропелевые илы (Черное море) и их аналоги (ДДВ); 2 - нанопланктонные известковые илы; 3 - эвапориты; 4 - мегаварвы; 5 - турбидиты; 6 - углеродистоглинистые осадки; 7 - углеродисто-глинисто-кремнистые осадки; 8 - углеродисто-кремнисто-фосфатно-известковые осадки; 9 - поверхности несогласий

бассейнов черноморского типа с признаками сопряженных процессов глубинной дегазации Земли, включая интенсивную флюидодинамику, сероводородно-метановое заражение и газогидратообразование [25]. Сероводородная и метановая дегазация обеспечивает интенсивные микробиогенные процессы, с которыми, как отмечалось, связана генерация основной массы ОВ ЧС эвксинского типа. Ведущую роль в указанном комплексе процессов, определяющем минеральный состав и геохимические особенности ЧС, играет донная флюидоотдача, обусловленная его "ситовой” (“рассеянный спрединг”) проницаемостью [9]. Она осуществляется через систему элементарных очагов разгрузки, морфология и “механизмы” функционирования которых применительно к черносланцевым формациям практически не изучены. В этом отношении они резко отличаются от гидротермально-рудоносных полей в Атлантическом и Тихом океанах и их древних аналогов - разновозрастных (кембрий - миоцен) колчеданных месторождений Урала, Рудного Алтая, Японии, Калифорнии, Кипра и др., сульфидные трубы которых аналогичны черным курильщикам (ЧК) — black smokers (рис. 10) [5].

ЧК представляют собой сложные системы. Их наиболее важным с точки зрения общих проблем естествознания (дегазация Земли - происхождение жизни эволюция) звеном является сопровождающая ЧК (при)гидротермальная специ- 


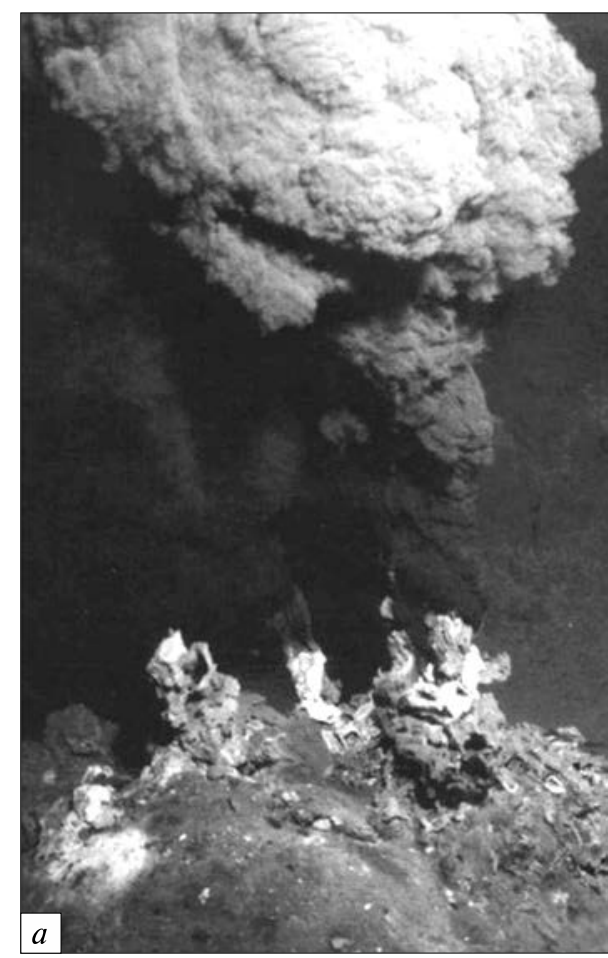

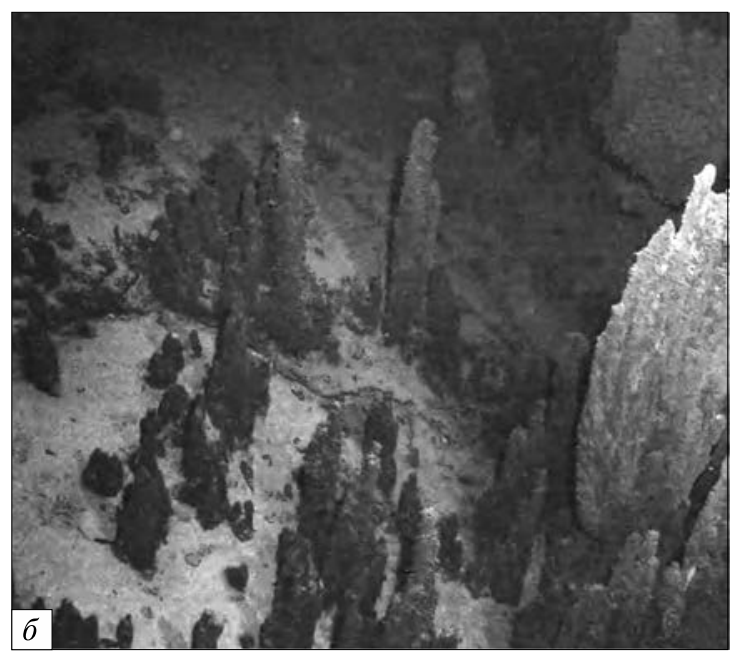

Puc. 10. Черные курильщики гидротермального поля Рейнбоу (Срединно-Атлантический хребет) [5]. $a$ - действующий ЧК; $\sigma-$ реликтовые сульфидные постройки

фическая биота, энергетической основой которой является бактериальный хемосинтез $[1,5,6,32]$. Более того, только наличие остатков этой биоты в виде поли-

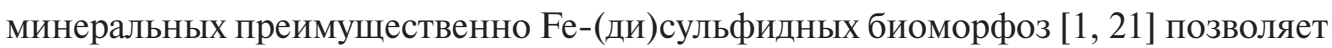
диагностировать древние аналоги ЧК. При этом следует учитывать известные закономерности эволюции литогенеза и, в частности, флюидного литогенеза [16], благодаря которым “палеокурильщики” могут кардинально отличаться от современных ЧК по размерам и морфологии, минеральному составу и геохимии, характеру микрофаций и их соотношению.

Одной из характерных особенностей как современных, так и древних (при)гидротермальных экосистем, помимо осуществляющих хемосинтез бактерий, является обязательное и доминирующее присутствие трубчатых червей вестиментифер, олигохет, полихет, а также разнообразной палеонтологической и литологической трубчатой проблематики [1, 23]. Обязательное присутствие таких организмов в указанных биоценозах и их доминирование в составе макробиоты, по-видимому, связано с тем, что они по мере отмирания играют роль микроканалов дегазации в иерархичных системах ЧК. Эта иерархичность - одно из ярких проявлений “фрактальной геометрии природы” [20].

По аналогии с современными (ЧК) и древними (сульфидные трубы на колчеданных месторождениях) гидротермальными полями океанического дна можно предполагать наличие в черносланцевых формациях эвксинского типа наличие минерализованных фрагментов каналов дегазации. При этом необходимо учитывать кардинальные различия процессов гидротермального рудообразования (гидротермальная активность океанического дна) и депрессионной гидрокарбопелитовой седиментации. Здесь следует отметить обнаруженные С.А. Ма- 

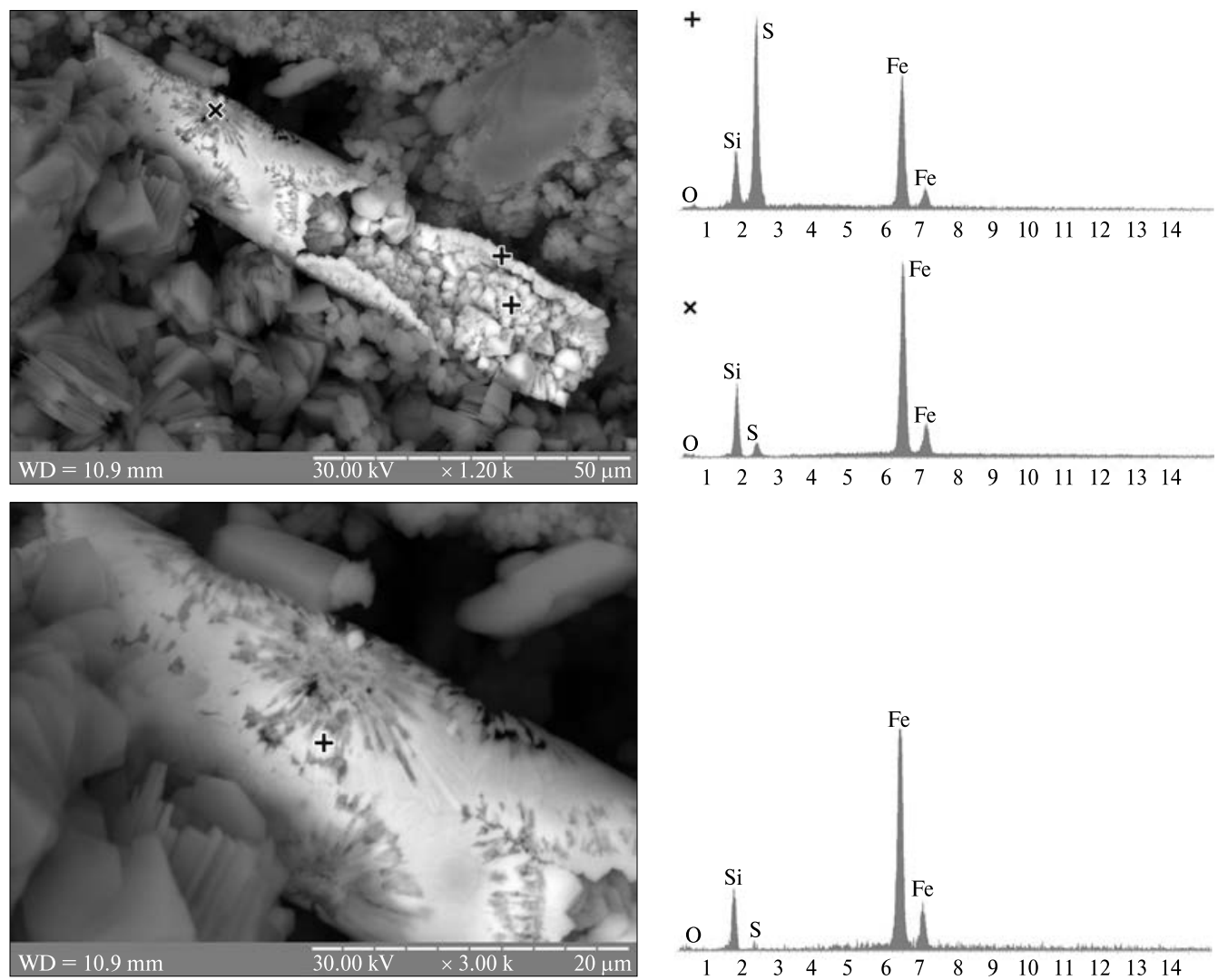

Puc. 11. (Ди)сульфидная псевдоморфоза по трубке "черного миникурильщика" (?), заполненной различными формами микробиогенной пиритизации (фрамбоиды, колломорфный и губчатый $\mathrm{FeS}_{2}$ ), с признаками кавитационного (?) разрушения стенок трубки в песчаниках-контуритах нижневизейской черносланцевой формации центральной части ДДВ (скв. 150-Березовская, инт. 5911-5914,8 м)

чулиной в нижнетурнейских карбонатных породах Стыльского карьера (юго-западная окраина Донбасса) фрагменты гидротермально-рудной структуры штокверкового типа, которую она описала в качестве ЧК [22]. Поскольку в [22] отсутствуют данные о (при)гидротермальной биоте, наличие биоморфоз которой является главным критерием сингенетичности рудной постройки и вмещающих рудоносных слоев [21], однозначно определить природу этой бесспорно интересной находки сложно. Она может быть связана как с эпигенетическим оруденением турнейских известняков в зоне интенсивной разломной тектоники, так и представлять собой аналог ЧК в существенно иных (по сравнению с гидротермальными полями современных и палеоокеанов) геологических условиях. При этом следует учитывать тот факт, что условия накопления шельфовых карбонатных отложений неблагоприятны для захоронения таких хрупких построек, как ЧК и сопутствующих им биоценозов, неизменным участником которых, как отмечалось, являются оруденелые трубчатые черви [21]. Условия депрессионной гидрокарбопелитовой седиментации в этом отношении гораздо благоприятнее, однако и здесь вероятность обнаружения минерализованных каналов конседиментационной дегазации невелика. Поэтому несомненный интерес представля- 

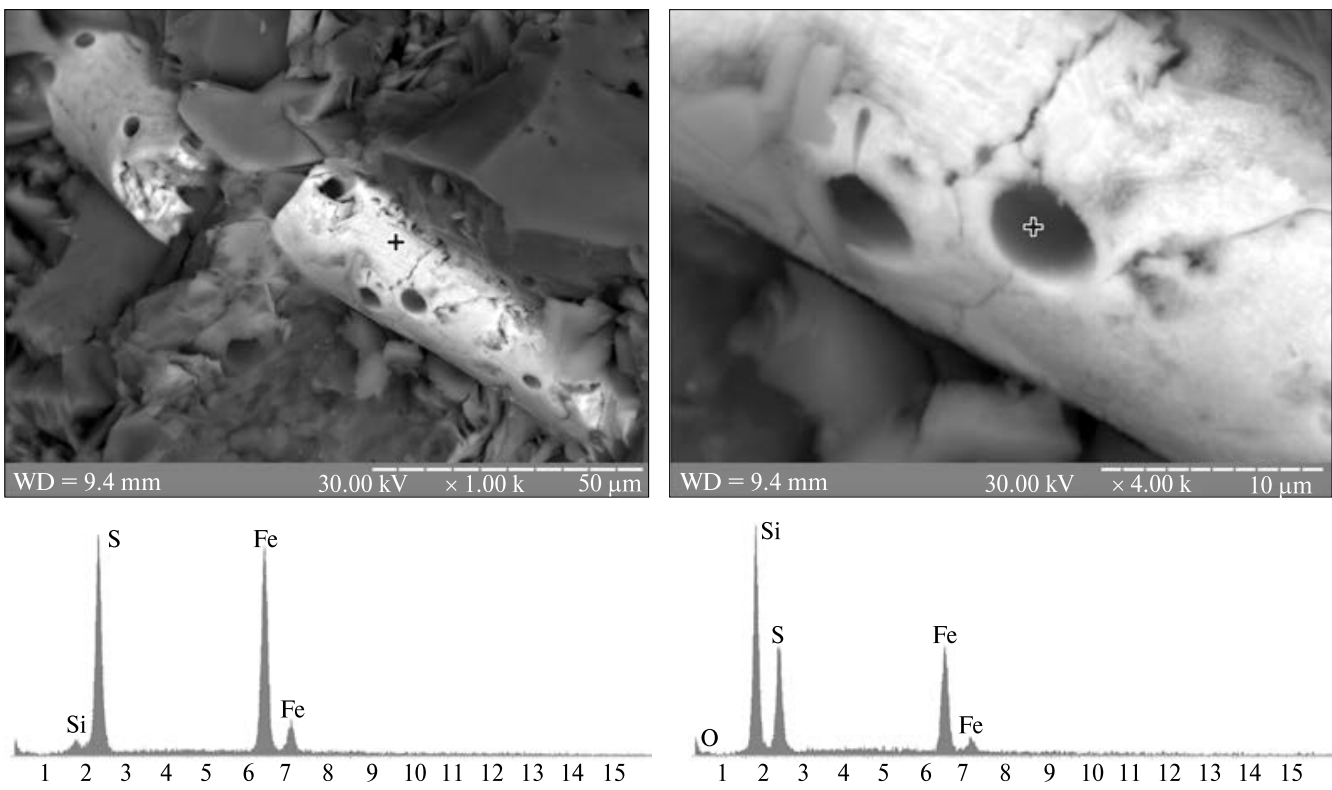

Puc. 12. (Ди)сульфидная псевдоморфоза по трубке "черного миникурильщика" с отверстиями микроэксплозивного (?) генезиса (кавитация?) в песчанике-контурите нижневизейской черносланцевой формации центральной части ДДВ (скв. 1-Перевозовская, инт. 6245-6256 м)

ют признаки присутствия возможных аналогов ЧК в визейских эвксинитах центральной части ДДВ. Содержание в них (ди)сульфидной серы варьирует от 0,4 до $2 \%$ и более. Она характеризуется преимущественно облегченным изотопным составом $\left(\delta^{34} \mathrm{~S}-10 \div-30 \%\right.$ ), что подтверждает ее бактериальную природу [15]. Однако в некоторых пробах отмечены существенно иные значения $\delta^{34} \mathrm{~S}$, близкие к метеоритному стандарту или несколько утяжеленные по сравнению с ним. Это характерно для участков интенсивной метасоматической пиритизации в парагенезе с карбонатизацией, окремнением и фосфатизацией. Вместе с тем значительное изотопное облегчение органической серы $\left(\delta^{34} S-10 \div-15 \%\right.$ свидетельствует о ведущей роли биохимического $\mathrm{H}_{2} \mathrm{~S}$ в процессах сульфуризации $\mathrm{OB}$, что характерно для илов-эвксинитов.

Изотопный состав (ди)сульфидной серы, таким образом, с одной стороны, свидетельствует о большой роли биохимического сероводорода, а с другой - о поступлении глубинного абиогенного $\mathrm{H}_{2} \mathrm{~S}$. В связи с этим особый интерес представляют обнаруженные при электронномикроскопическом изучении ЧС и залегающих среди них песчаных тел депрессионного генезиса фрагменты пиритизированных трубок цилиндрической и конусовидной формы, заполненных колломорфным, губчатым и фрамбоидальным пиритом, включающим значительную часть вмещающих ЧС (рис. 11, 12). По-видимому, это фрагменты микротрубчатой дегазационной системы, по которой в бассейн седиментации поступал глубинный сероводород. Отверстия в стенках трубок свидетельствуют о распылении двухфазного флюида на капли жидкости и пузырьки газа, при кавитации которых происходили микровзрывы, перфорирующие стенки трубок. Именно с процессами распыления струйной миграции глубинного флюида и связан феномен ЧК. Сопутствующие гидротермальным существенно сульфидным трубообразным и 

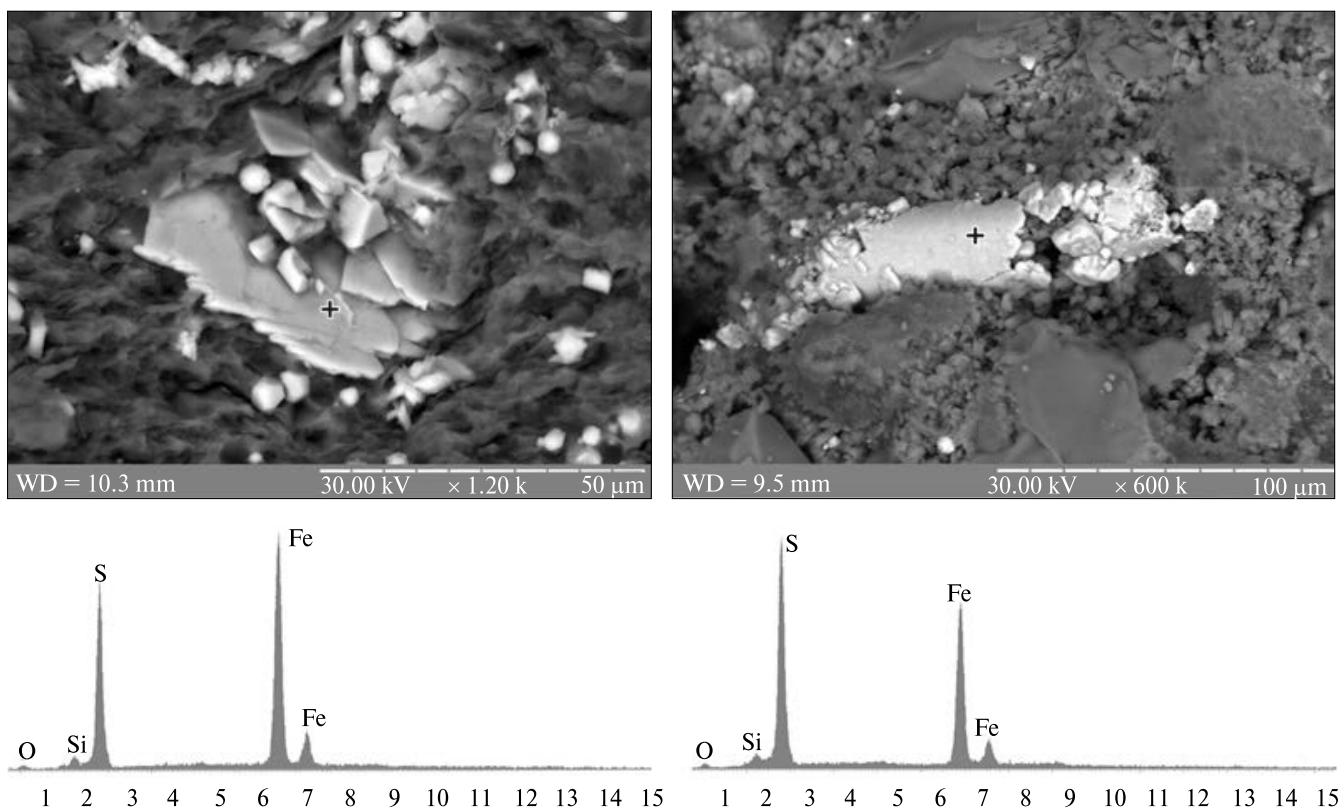

Puc. 13. Различная степень разрушения (ди)сульфидной псевдоморфозы по трубке “черного миникурильщика" (?) в гидрокарбопелитах и песчаниках-контуритах (обломки стенки трубки и ее содержимое - различные формы ассоциаций микробиогенных кристаллов $\mathrm{FeS}_{2}$, колломорфный и губчатый пирит, суб- и эвгедральные кристаллы пирита) нижневизейской черносланцевой формации центральной части ДДВ (скв. 150-Березовская, инт. 5911-5914,8 м; инт. 5920-5924 м)

конусовидным постройкам (см. рис. 10) на океаническом дне черные “дымы” представляют собой взвесь сульфидных капельных частиц, образующихся при смешении глубинных высокоэнтальпийных флюидов (насыщенных сероводородом и другими газами, железом и другими металлами) с холодными придонными морскими водами [6, 19, 30].

Сопутствующая ЧК (при)гидротермальная биота и прежде всего трубчатые организмы очень быстро (в считанные дни) минерализуются (ди)сульфидом железа и другими сульфидами, отмирают и становятся миниканалами фильтрации глубинных флюидов [30]. Капли $\mathrm{FeS}_{2}$ оседают на дно в виде (ди)сульфидного “дождя” - одного из факторов формирования гидротермальных полей на океаническом дне [5, 21].

Аналогичные по своей физической сути процессы происходят в “факеле распыления - капельно-газовой струе, которая образуется при встрече жидкой струи с газовым потоком в центральной форсунке” [3, с. 140]. В данном же случае мы имеем дело с аналогичными процессами в “миникурильщиках", которые легко разрушаются вследствие кавитации газовых пузырьков. Степень разрушения различна (рис. 11-13), но неизбежна вследствие хрупкости этих трубок. Это, в частности, позволяет объяснить обилие и многообразие (ди)сульфидных агрегатов в ЧС эвксинского типа (рис. 13, 14).

Обнаружение в керне глубокозалегающих нижневизейских ЧС центральной части ДДВ фрагментов пиритизированных трубок цилиндрической и конусовид- 

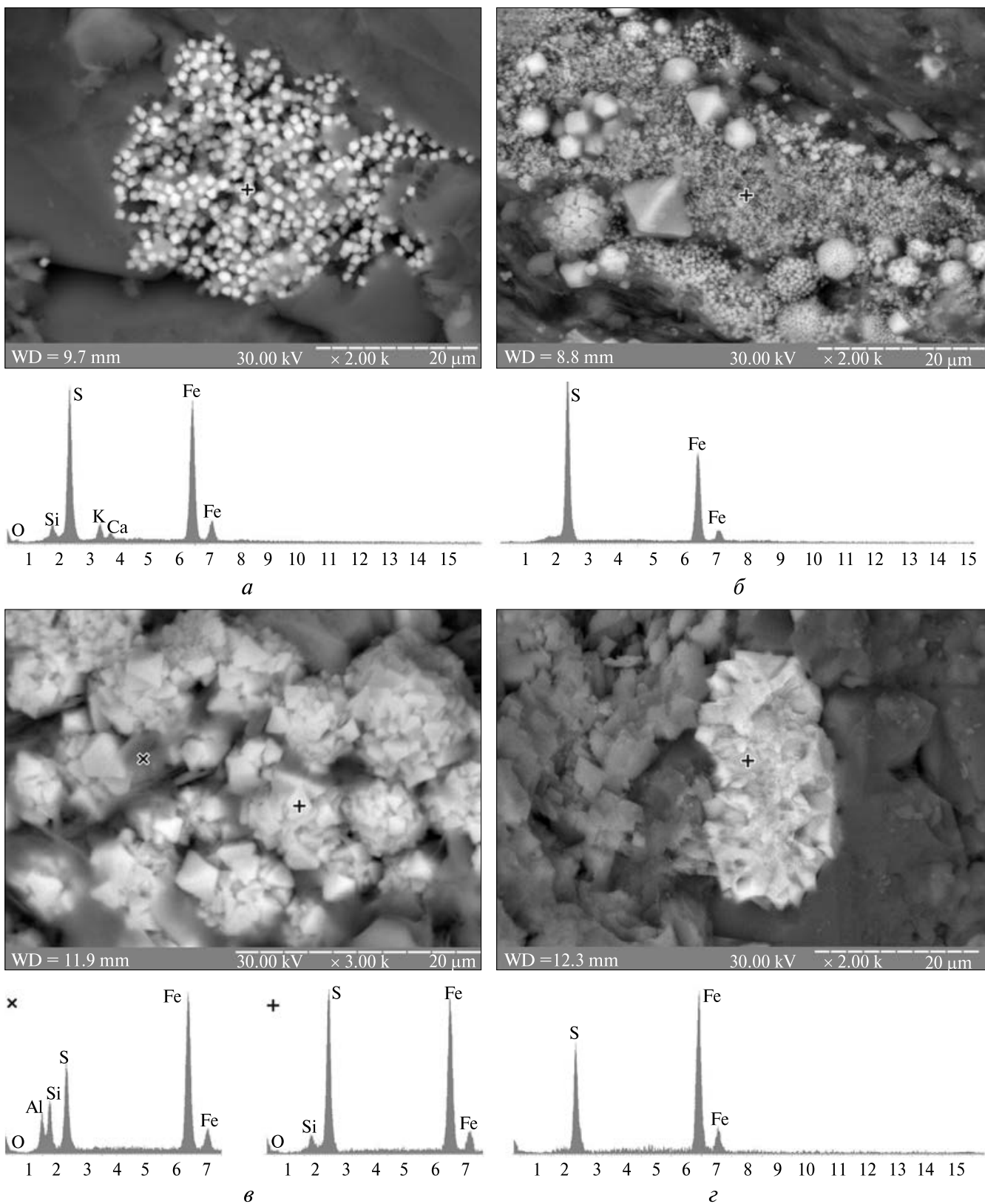

Puc. 14. Различные типы агрегатов $\mathrm{FeS}_{2}$ - дериваты “черных миникурильщиков” в гидрокарбопелитах и песчаниках-контуритах нижневизейской черносланцевой формации центральной части ДДВ. $a-$ - ди)сульфидный "дождь" (скв. 1-Мехедовская, инт. 4865-4881 м); $\sigma-$ (ди)сульфидный “дождь”, фрамбоидальный пирит, суб- и эвгедральные кристаллы пирита (скв. 17-Семиренковская, инт. 5960-5966 м); в - скопление агрегатов эвгедрального, биогенного губчатого и колломорфного пирита (скв. 1-Перевозовская, инт. 6245-6256 м); г - микробиогенный губчатый агрегат $\mathrm{FeS}_{2}$ (скв. 485-Березовская, инт. 4665-4668 м)

ной формы - детрита предполагаемой микротрубчатой дегазационной системы, по которой в бассейн поступал глубинный сероводород, представляет особый интерес в свете обнаруженных 25 лет назад сульфидных построек на дне Черного моря [4]. Это еще один (причем особо убедительный в контексте с уолсортскими 
фациями и признаками метановых сипов) аргумент в пользу эвксинского характера ранневизейского Придобруджинско-Днепровско-Донецкого палеобассейна. Вместе с тем, сравнительная характеристика (ди)сульфидных построек современных (и древних) гидротермальных полей рифтовых зон океанов (с ЧК и сопровождающей их специфической биотой), ранневизейского эвксинского бассейна и Черного моря имеет первостепенное значение для изучения эволюции флюидного литогенеза - одной из наиболее актуальных проблем современной седиментологии [16].

Здесь следует отметить существенные отличия черноморских (ди)сульфидных (существенно пиритовых) образований как от ЧК гидротермальных полей, так и, в меньшей мере, от черных миникурильщиков ранневизейских черносланцевых отложений. Их открытию предшествовали многолетние исследования газогидратных скоплений, метановых сипов и парагенетичных им разнообразных карбонатных образований (плиты, коралловидные и башнеподобные постройки) [25, 26]. В октябре 1993 [25] и июне 1994 г. во время рейсов нис “Профессор Водяницкий” на поле газовыделений в северо-западной части Черного моря на полигоне по изучению газовых струй (сипов), наряду с обломками карбонатных сооружений, были подняты разнообразные фрагменты (до)сульфидных минеральных агрегатов: корок, полых трубок и “верхушек хорошо сохранившихся небольших сульфидных построек, возвышавшихся над дном” [4, с. 576]. Из приведенных в [4, 25] данных следует резко выраженный подчиненный характер распространения (до)сульфидных построек по отношению к сипам и карбонатным постройкам. Область развития сипов гораздо шире и захватывает бровку шельфа и его крутой склон (свал глубин 100-500 м), тогда как указанные сульфидные образования были подняты пока только в одном месте с глубины 198 м. По-видимому, область их развития несколько смещена по сравнению с областью распространения метановых сипов, и с глубиной их количество возрастает. Как отмечают авторы [4, с. 577], “особый интерес представляют обломки полых сульфидных трубок, напоминающих трубки знаменитых черных курильщиков”. Однако, как и (ди)сульфидные трубки и конусы, обнаруженные в ранневизейских эвксинитах (см. рис. 11, 12), они отличаются от ЧК современных гидротермальных полей в области океанического рифтогенеза $[1,5,6,30]$ и их древних аналогов - колчеданных месторождений [21] - размерами, минеральным составом и геохимией. В отличие от типичных современных и древних ЧК они, как и их ранневизейские аналоги, характеризуются мономинеральным пиритовым составом с незначительными (менее $0,1 \%$ ) примесями $\mathrm{Mn}, \mathrm{Cu}, \mathrm{Zn}, \mathrm{Ag}$. В одной из проб (обломок пиритовой корки с черным сажистым налетом $\mathrm{FeS}_{2}$ ) обнаружено повышенное содержание мышьяка $(0,11 \%)$. Если при этом учесть ограниченное (9) количество изученных проб, а также неясный источник железа, то утверждение “можно ... быть твердо уверенным, что этот (фиксированный в пиритовых постройках) сероводород имеет биогенное, а не гидротермальное происхождение" [4, с. 679].

Что касается изотопного состава серы, то ее аномальная утяжеленность $\left(\delta^{34} \mathrm{~S}\right.$ $+14,0+16,7 \%$ \%) не может рассматриваться как однозначное доказательство микробного генезиса $\mathrm{H}_{2} \mathrm{~S}$, поскольку “глубоко зашедший процесс восстановления сульфатов" [4, с. 679] может быть связан и с эндогенными факторами. Черные сажистые налеты на внутренней стороне корок и внутри трубок, по-видимому, являются продуктами “черных дымов” этих аналогов ЧК при всех их существенных 
морфологических и вещественных различиях. Разумеется, определить источники $\mathrm{H}_{2} \mathrm{~S}$, фиксированного в сульфидных постройках дня Черного моря, также, как и их несомненных близких аналогов в нижневизейских эвксинитах весьма затруднительно. Однако его глубинное происхождение несомненно.

Таким образом, находка, как на дне Черного моря, так и в отложениях ранневизейского эвксинского бассейна этих хрупких эфемерных образований, предположительно являющихся аналогами ЧК, подчеркивает единство закономерностей накопления черносланцевых формаций эвксинского типа.

Следует подчеркнуть принципиальное сходство ранневизейского и позднекайнозойского этапов развития соответственно Палеотетиса и Паратетиса, когда этот (палео)океан распадался на (полу)замкнутые бассейны эвксинского типа. Это полностью подтверждает вывод в недавно изданной фундаментальной монографии по газовому вулканизму Черного моря, согласно которому “в геологотектоническом отношении развитие Азово-Черноморского региона связано с раскрытием и закрытием океана Тетис" [25, с. 328]. Возникающие при этом резонансные (в понимании Ю.М. Пущаровского) структуры, к которым относится мегавпадина Черного моря и ее древние аналоги, наложены на систему различных (от платформенных до складчато-орогенных) тектонических структур.

Ведущая роль эндогенных факторов ранневизейской седиментации ярко проявляется на южной окраине Донбасса, где соответствующая низам рассматриваемого стратона подзона $\mathrm{C}_{1} \mathrm{ve}_{2}$ представляет собой флишоидную пачку (2050 м), представленную тонким переслаиванием черных спонголитов, листоватых известково-сапропелевых пород (типа “бумажных сланцев”) и светлоокрашенных (кремовых, ярко-желтых и др.) туфовых глин. Последние состоят из смектитов и магнезиальных силикатов, образовавшихся за счет гальмиролиза пеплового материала и эксгаляционного синтеза [15]. Минералогический состав и петрохимические особенности свидетельствуют о связи их с высокомагнезиальным андезитовым магматизмом островодужного типа. По-видимому, южная окраина Донбасса является фрагментом палеоостровной дуги, разделявшей палеоокеан (Палеотетис) и задуговый Придобруджинско-Днепровско-Донецкий палеобассейн эвксинского типа (см. рис. 6). Наличие рифового обрамления визейских эвксинитов в Придобруджинском прогибе и ДДВ, а также присутствие обломков (размерностью - от гравия до глыб и крупных блоков - олистолитов) шельфовых и рифовых нижнекарбоновых известняков в составе выделенного В.В. Юдиным Симферопольского полимиктового вулканогенно-осадочного меланжа (с возрастом обломков разнообразных пород от раннего карбона до раннего мела) свидетельствуют о связи с этой островодужной границей барьерно-рифового пояса [15].

“Закрытие” соответствующего палеоокеана, разрыв единого задугового эвксинского палеобассейна на отдельные фрагменты сопровождался поглощением соответствующей, падающей в северном направлении под ВЕП, зоной субдукции колоссальных объемов депрессионных отложений, обогашенных сапропелевым ОВ $[10,15]$. С этим явлением связана одна из важных автономных углеводородогенерирующих систем Азово-Черноморского региона [15]. По-видимому, по аналогичной схеме (задуговый эвксинский бассейн - палеоокеан, с последующим закрытием второго и разобщением на отдельные фрагменты первого) протекала фанерозойская тектоно-геодинамическая эволюция АЧР как части Пале- 
отетиса. При этом положение палеорифтовых систем, палеоостровных дуг и зон субдукции существенно менялось, о чем свидетельствуют сейсмогеологические данные, характер распространения разновозрастных рифовых известняков, результаты палеогеографических и палеотектонических реконструкций. Это определяет положение зон (ареалов) нефтегазонакопления и степень их перспективности в двух историко-геологически и палеогеодинамически тесно связанных нефтегазоносных регионах Украины - Восточном (Днепровско-Донецком) и Южном (Азово-Черноморском).

\section{СПИСОК ЛИТЕРАТУРЫ}

1. Биология гидротермальных систем. Ред. А.В. Гебрук. Москва: KMK Press, 2002. 543 с.

2. Блохіна Т.С. Сапропелеві мули Чорного моря (речовинний склад, генезис та перспективи використання): автореф. дис. ... канд. геол.-мін. наук. 04.00.10. Ін-т геол. наук НАН УКраїни. Київ, 1994. 25 с.

3. Волынский М.С. Необыкновенная жизнь обыкновенной капли. Москва: Знание, 1986. $144 \mathrm{c}$.

4. Леин А.Ю., Егоров В.Н., Пименов Н.В. и др. Сульфидные постройки со дна Черного моря. Докл. РАН. 1995. Т. 340, № 5. С. 676-680.

5. Леин А.Ю., Сагалевич А.М. Курильщики поля Рейнбоу - район масштабного абиогенного синтеза метана. Природа. 2000. № 8. С. 44-54.

6. Лобье Л. Оазисы на дне океана. Ленинград: Гидрометиздат, 1990. 156 с.

7. Лукин А.Е. Дегазация Земли, химический мутагенез, макроэволюция. Палеонтология в системе естественных наук. Санкт-Петербург, 1999. С. 48-49.

8. Лукин А.Е. Изотопно-геохимические индикаторы углекислой и углеводородной дегазации в Азово-Черноморском регионе. Геол. журн. 2003. № 1. С. 59-73.

9. Лукин А.Е. Литогеодинамические факторы нефтегазонакопления в авлакогенных бассейнах. Киев: Наук. думка, 1997. 225 с.

10. Лукин А.Е. О Днепровско-Донецком средневизейском палеобассейне эвксинского типа. Докл. РАН. 1995. Т. 344, № 5. С. 660-664.

11. Лукин А.Е. О природе и перспективах газоносности низкопроницаемых пород осадочной оболочки Земли. Докл. НАН Украины. 2011. № 3. С. 114-123.

12. Лукин А.Е. О природе трещиноватости нефтегазоносных коллекторов с плотной матрицей. Доп. НАН України. 2015. № 6. С. 114-122.

13. Лукин А.Е. О происхождении нефти и газа (геосинергетическая концепция природных углеводородно-генерирующих систем). Геол. журн. 1999. № 1. С. 30-42.

14. Лукин А.Е. Природа сланцевого газа в контексте проблем нефтегазовой литологии. Геология и полезн. ископ. Мирового океана. 2011. № 3. С. 70-86.

15. Лукин А.Е. Средневизейский эвксинский бассейн в системе Палеотетиса. Геодинамика и нефтегазоносные структуры Черноморско-Каспийского региона. Сб. докл. IV междунар. конф. “Крым-2002”. Симферополь, 2003. С. 154-168.

16. Лукин А.Е. Флюидный литогенез - важнейшее направление литологических исследований в XXI столетии. Геол. журн. 2014. № 4. С. 8-26.

17. Лукин А.Е. Черносланцевые формации эвксинского типа - мегаловушки природного газа. Геология и полезн. ископ. Мирового океана. 2013. № 4. С. 5-28.

18. Лукин А.Е., Гафич И.П., Макогон В.В., Холодных А.Б. Перспективы нефтегазоносности глубокозалегающих уолсортских карбонатных куполов в центральной части ДнепровскоДонецкой впадины. Доп. НАН України. 2016. № 8. с. 70-78.

19. Лукин А.Е., Резников А.И., Кривошеев В.Т., Ларченков А.Я. О строении карбона Днепровско-Донецкого авлакогена. Докл. АН СССР. 1980. Т. 251, № 1. С. 176-179.

20. Мандельброт Б. Фрактальная геометрия природы. Москва: Мир, 1975. 350 с.

21. Масленников В.В., Аюпова Н.Р., Масленникова С.П., Целуйко А.С. Гидротермальные биоморфозы колчеданных месторождений: микротекстуры, микроэлементы и критерии обнаружения. Екатеринбург: РИО УрО РАН, 2016. 388 с. 
22. Мачулина С.А. Геологические условия формирования “черного курильщика” в Донбассе. Доп. НАН України. 2008. № 12. С. 107-110.

23. Несис К.Н. Вестиментиферы. Природа. 1984. № 4. С. 87-89.

24. Толковый словарь английских геологических терминов. Москва: Мир, 1987. Т. 1. 585 с. Т. 2. 587 c. T. 3.590 c.

25. Шнюков Е.Ф., Коболев В.П., Пасынков А.А. Газовый вулканизм Черного моря. Киев: Логос, 2013. $384 \mathrm{c}$.

26. Шнюков Е.Ф., Леин А.Ю., Егоров В.Н. и др. Обнаружение в Черном море глубоководных карбонатных построек биогенного происхождения. Докл. НАН Украины. 2004. № 1. C. $118-122$.

27. Шнюков Е.Ф., Старостенко В.И., Гожик П.Ф. и др. О повышенной газоотдаче дна Черного моря. Геол. журн. 2001. № 4. С. 7-14.

28. Юдин В.В. Микститы Горного Крыма. Докл. РАН. 1995. Т. 344, № 5. С. 660-664.

29. Юдович Я.Э., Кетрис М.П. Геохимия черных сланцев. Ленинград: Наука, 1988. 272 с.

30. Fornari D.J., Embley R.W. Tectonic and volcanic controls on hydrothermal processes at the midocean ridge: An overview based on near-bottom and submersible studies. Seafloor Hydrothermal Systems: Physical, Chemical, Biological and Geological Interactions. Ed. S.E. Humphris el al. Geophysical Monograph Series. 1995. V. 91. P. 1-46.

31. Jenkins H.C. Cretaceous anoxic events from continents to oceans. J. Geol. Soc. London, 1973. V. 137, № 2. P. $171-188$.

32. Jones M.L. Riftia pachiptila Jones Observations on the Vestimentiferan worms from Galapagos Rift. Science. 1981. V. 213. 333 p.

33. Lees A. Waulsortian. Geological Belgian. 2006. № 1-2. P. 151-153.

34. Lukin A. Middle Visean anoxic event. Proceedings of the XIII Internat. Congress on Carboniferous. Permian. Krakov. P. 1-4.

О.Ю. Лукін, академік НАН України, доктор геол-мін. наук, професор Інститут геологічних наук НАН України, Київ

01054, м. Київ, вул. Олеся Гончара, 55-б

E-mail: lukin_alexander@ukr.net,

ORCID 0000-0003-4844-1617

\section{РАННЬОВІЗЕЙСЬКИЙ ЕВКСИНСЬКИЙ БАСЕЙН \\ В СИСТЕМІ ПАЛЕОТЕТІСУ (У СВІТЛІ СУЧАСНИХ ДАНИХ)}

Серед давніх різновікових басейнів евксинського типу особливо виділяється своєю дивовижною схожістю з Чорним морем ранньовізейський басейн, фрагменти якого приурочені до Дніпровсько-Донецької западині, а також Придобруджинського прогину. Зазначена схожість перш за все стосується зіставлення голоцену Чорного моря і інтервалу, що відповідає рудівським верствам нижнього візе. Це типові чорносланцеві (гідрокарбопелітові) формації, які накопичуються в умовах інтенсивної газовіддачі $\left(\mathrm{CH}_{4}-\mathrm{H}_{2} \mathrm{~S}-\mathrm{CO}_{2}\right)$ дна морського басейну з обмеженою циркуляцією і анаеробними мікробіогенними факторами седиментації. У Придобруджинсько-Дніпровсько-Донецькому евксинському басейні ранньокам'яновугільний етап седиментації в умовах евксинського режиму включав також турнейсько-ранньовізейську фазу карбонатонакопичення. Вона характеризується відсутністю типових “екологічних” рифів і представлена темнокольоровими (з підвищеним вмістом керогену і мікробіогенного піриту) пелітоморфними вапняками (карбонатними чорними сланцями). Фактично це карбонатні мікробіогенні (за підпорядкованої участі макрофлори: криноідей, брахіопод) споруди, сформовані на депресійному дні в умовах тісної взаємодії вуглекислої і метанової, а також сірководневої глибинної дегазації. Були виявлені фрагменти піритизованих трубок циліндричної і конусоподібної форми, заповнених коломорфним, губчастим і фрамбоїдальним піритом, що відіграє велику роль в складі чорних сланців. Мабуть, це фрагменти мікротрубчастої системи дегазації, якою в басейн седиментації надходив глибинний сірководень. Отвори в стінках трубок свідчать про розпилення двофазного флюїду на краплі рідини і бульбашки газу, при 
кавітації яких відбуваються мікровибухи, що перфорують стінки трубок. Знахідка цих крихких ефемерних утворень, які ймовірно $€$ аналогами чорних курців, дозволяє конкретизувати закономірності накопичення чорносланцевої формацій евксинського типу, що має сприяти як освоєнню пов'язаних з ними вуглеводневих і мінеральних ресурсів, так й оцінці їх геоекологічного і еволюційно-біологічного значення.

Ключові слова: евксинський басейн, чорні сланці, сірководнева дегазація

\author{
A.E. Lukin, Acad. of NAS of Ukraine, \\ Dr. Sci. (Geol. \& Mineral.), Prof. \\ Institute of Geological Sciences of NAS of Ukraine, Kyiv \\ 55-b, O. Honchara str., Kyiv, Ukraine, 01054 \\ E-mail: lukin_alexander@ukr.net \\ ORCID 0000-0003-4844-1617
}

\title{
EARLY VISEAN EUXINIC BASIN IN THE SYSTEM OF PALEO-TETHYS (IN THE LIGHT OF MODERN DATA)
}

Among ancient euxinic basins of different age and geotectonic position there is one basin deserving of special attention. This is Early-Visean basin in the system of Paleo-Tethys which possess by striking similarity with the Black sea. The fragments of this basin are connected with Dnieper-Donets depression and Pre-Dobrudga foredeep. This statement about similarity is true for comparative characteristic of Holocene of the Black sea and the time interval which corresponds to rudovski strata. These are typical black shale (hydrocarbopelites) formation which accumulated under conditions of intensive gas-rejection of the sea bottom $\left(\mathrm{CH}_{4}-\mathrm{H}_{2} \mathrm{~S}-\mathrm{CO}_{2}\right)$. Similary to the Black sea this Early-Visean basin had restricted circulation anaerobic regime of sedimentation. Predobrudge-Dnieper-Donets basin also included into euxinic the carbonate phase of euxinic sedimentation. It is characterized by the absence of typical ecologic reefs and are represented by the Waulsortian facies (mud mounds) - dark-coloured micritic limestones (with in creased content of kerogen and microbiogenic $\mathrm{FeS}_{2}$ ) - carbonate black shales. Nature of this mud mounds is connected with physic-chemical (travertine formation) and microbiogenic processes which connected with gas seeps. They are characterized by intimately related $\mathrm{CH}_{4}-\mathrm{CO}_{2}-\mathrm{H}_{2} \mathrm{~S}$ degassing. Fragments of pyritizited tubes of cylinder or cane-shaped shapes have been detected as a result of examining under electronic-microscope the rocks of black shale formation (Lower Visean, Dnieper-Donets depression, the cores of oil and gas deep (wells). This tubes are filled by (with) colomorphic, spongic and framboidal forms of microbiogenic pyrite. It constitutes the considerable portions of enclosing black shales. These tubes and associated forms of pyrite are supposedly the segments of microchimney system of deep $\mathrm{H}_{2} \mathrm{~S}$-degassing. It seems likely that the holes in the walls of these tubes made connected with cavitations of gas bubbles. Their appearance were connected with spraying of two-phased fluid flow. Cavitation microexplosions perforated the tube walls. These brittle ephemeric structures are possible analogues of black smokers. Their discovery allow to reveal the geological conditions of euxinic of black shales. That in turn should promote the development of these formations as a nontraditional source of hydrocarbons and different metals.

Keywords: euxinic basin, black shales, hydrogen sulphide degassing. 